\title{
Crustal evolution of the Saykhandulaan Inlier, Mongolia: Implications for Palaeozoic arc magmatism, polyphase deformation and terrane accretion in the Southeast Gobi Mineral Belt
}

\author{
James H.S. Blight ${ }^{\text {a }}$, Dickson Cunningham ${ }^{\text {a }}$, Michael G. Petterson ${ }^{\text {b }}$ \\ ${ }^{a}$ Department of Geology, University of Leicester, UK \\ ${ }^{\mathrm{b}}$ British Geological Survey, Keyworth, UK
}

\begin{abstract}
The Saykhandulaan Inlier in South East Mongolia lies within the Central Asian Orogenic Belt (CAOB), and records Palaeozoic continental accretion on the northern margin of the Palaeo-Asian ocean. The inlier spans the boundary between two important terranes of the CAOB. The Gobi Altai back-arc basin terrane in the north formed between the continental core of Mongolia, and the arc terranes of the CAOB. The Mandalovoo island arc terrane hosts many mineralised intrusions and was laterally equivalent to the arc that hosts the Oyu Tolgoi gold-rich copper porphyry deposit to the south.

Fieldwork traverses across the structural grain of the Saykhandulaan inlier have established five parallel E-W-elongate litho-tectonic domains; the Northern Slate Belt, comprised of Devonian greenshist grade pelites and psammites, with deep-marine to coastal silici-clastic protoliths; the Saykhandulaan Valley Lineament Zone, comprising a zone of faulting featuring slivers of altered volcanic stratigraphy; the High Strain Belt, composed of tightly folded and flattened meta-clastic rocks; the Molasse Sucession (MS), relatively undeformed coarse conglomerates and sandstones and the Oyut Ulaan Volcanic Group, a folded volcanic-sucession, up to $5 \mathrm{~km}$ thick. The Oyut Ulaan Volcanic rocks host a mid-Carboniferous mineralised granite; the Oyut Ulaan intrusion.

The Northern Slate Belt records a cratonic provenance, whereas all parts of the inlier to the south have arc affinities. The Saykhandulaan Valley Lineament Zone divides the area into northern and southern provenance domains, and delineates the boundary between the Gobi Altai and Mandalovoo terranes.

Two major deformation events are identified following basin closure; related to basin inversion $\left(D_{1}\right)$ and accretion of the Mandalovoo arc-terrane $\left(D_{2}\right)$. Basin inversion resulted in regional scale folding and greenschist grade metamorphism in the Northern Slate and High Strain Belts. During terrane accretion the Oyut Ulaan Volcanic Group was folded and thrusting took place along the Saykahndulaan Valley Zone, exhuming the highly deformed rocks of the High Strain Belt. Subsequent to the cessation of subduction, crustal extension and strike-slip faulting have further modified the crustal architecture of the inlier. The results presented here provide a useful framework for understanding the crustal evolution of adjacent regions within the southeast Gobi mineral belt.
\end{abstract}




\section{Introduction}

The Gobi region of southeastern Mongolia lies within the Central Asian Orogenic Belt (CAOB), Earth's largest area of Phanerozoic continental growth, and is a natural laboratory for documenting processes of terrane accretion and amalgamation. Important mineral deposits have been discovered in the SE Gobi region during the last decade and consequently the region is now a major mineral exploration province. Nevertheless, few studies exist documenting the basement evolution and lithotectonic context of the SE Gobi mineral belt. This is partly because the area is remote, has low relief, and in general, displays poor outcrop exposure. However, the Saykhandulaan Inlier (Fig. 1), which crops-out 400km to the south of Ulaan Baatar is unusual because it contains a large area of basement exposure and provides a good opportunity for unravelling the major tectonic, metamorphic and intrusive events that have affected the SE Gobi mineral belt. In addition, it hosts the Oyut Ulaan $\mathrm{Cu}$-Au porphyry prospect and is along strike of other major exploration targets in the region. Therefore, a detailed multidisciplinary study incorporating field investigations and structural and geochemical analysis was carried out during 2004-2006 to document the crustal evolution of the Saykhandulaan Inlier and the terrane context of SE Gobi mineralisation.

\subsection{Regional geology}

The CAOB records terrane accretion and crustal growth between the Angaran craton (also known as the Siberian Craton) and the North China Craton from the Late Precambrian to Permian (Fig. 1). The CAOB reaches from Kazakhstan to Eastern 
Siberia and averages around 300km wide (Xiao et al., 2003; 2004). Terranes in Southern Mongolia lie within the CAOB, to the north of the main Permian Solonker suture, which marks the final closure of the Palaeo-Asian Ocean in the Permian (Xiao, 2003). The basement geology of South Mongolia consists of island-arc, backarc/forearc basin and accretionary prism terranes that accreted around a Precambrian cratonic block that lies under the Hangay Dome in central Mongolia (Fig. 1; Sengor and Natal'in, 1996; Badarch et al. 2002). These terranes record the tectonic evolution of the northern margin of the Palaeo-Asian Ocean during the Palaeozoic, generally interpreted to have taken place above a northward dipping subduction zone.

Two hypotheses exist for the formation of the Mongolian CAOB crust during the Palaeozoic. Şengör and Natal'in (1996), postulated one long-lived island-arc, with a complex history of magmatic front migration, strike-slip motion and oroclinal bending along its length prior to terminal accretion (Fig. 2a). An alternative model by Badarch et al (2002), proposed the existence of multiple island arcs drifting across the Palaeo-Asian Ocean and accreting various arc-marginal basin terranes and ophiolite slivers before terminal collision against the southern margin of Siberia/Hangay (Fig. $2 b)$.

Badarch et al. (2002) suggest that southeastern Mongolia is dominated by two Ordovician-Carboniferous island-arc terranes (Fig. 1), the Gurvansaykhan and Mandalovoo terranes, which are surrounded by back-arc/fore-arc basins; the Ordovician-Carboniferous Gobi Altai terrane to the north and the Nuhetdavaa terrane to the south. The Gurvansaykhan and Mandalovoo terranes are interpreted to have originally been along-strike equivalents of the same island arc, but dextral strike-slip faults shunted the Gurvansaykhan terrane southwest to its current location. South of 
these two terranes, near the Sino-Mongolian border, a series of parallel island-arc, accretionary wedge and cratonal terranes record a separate subduction-accretion history (Figs. 1, 2; Badarch et al 2002).

Subsequent to Palaeo-Asian suturing at the end of the Permian, Mongolia underwent several periods of intracontinental deformation. Left-lateral strike-slip faults were active in southeast Mongolia from the Triassic to late Cretaceous (Lamb et al., 1999) and between $185-235 \mathrm{~km}$ of left-lateral offset occurred along the Zuunbayan Fault, which forms the southeast margin of the Gurvansaykhan terrane (Fig. 1). Further west, a Jurassic contractional phase of deformation is expressed by E-W trending thrust faults along the Mongolian-Chinese border (Zheng et al., 1996). Southeast Mongolia and adjacent regions of China experienced a major phase of NWSE crustal extension during the Jurassic-Cretaceous (Meng et al., 2003). JurassicCretaceous clastic and volcanic stratigraphy fill low-relief basins throughout the region including areas adjacent to the Saykhandulaan Inlier. The rifting is interpreted to be a distal effect of Pacific-rim back-arc extension (Graham et al., 2001). Cretaceous-Tertiary thermal uplift and volcanism are widely distributed in central, southern and southeastern Mongolia and are possibly related to a steady state thermal anomaly in the mantle beneath Mongolia and Eastern China (Barry and Kent, 1998). Sinistral transpressional deformation driven by the Indo-Eurasia collision, has reactivated the Gobi Altai region in south and west Mongolia during the late Cenozoic (Cunningham, 1998). However, there is only limited evidence for renewed tectonism in southeast Mongolia (Webb and Johnson, 2006)

Major porphyry copper discoveries in the region include the Oyu Tolgoi goldrich deposit, which occurs within the Gurvansaykhan arc terrane, $260 \mathrm{~km}$ to the southwest of the Saykhandulaan Inlier (Fig. 1; Badarch et al., 2002). Mineralisation 
at Oyu Tolgoi is associated with arc related Siluro-Devonian porphyry magmatism intruded into lavas and clastic sedimentary rocks (Perello et al., 2001). Another important deposit is Tsagaan Suvarga, a copper-molybdenum porphyry hosted in a Devonian calc-alkaline granite complex, $120 \mathrm{~km}$ southwest of the Saykhandulaan Inlier (Fig. 1; (Watanabe and Stein, 2000). To the north, the Mandalovoo terrane also contains several porphyry-style prospects in an east-west trending belt. Part of the Mandalovoo terrane lies within the Saykhandulaan Inlier and contains the Oyut Ulaan copper-gold prospect (Fig. 1).

\section{Geology}

The Saykhandulaan Inlier spans the boundary between the Gobi Altai terrane to the north, and the Mandalovoo terrane to the south (Fig. 1). The Saykhandulaan Valley Lineament Zone (SVLZ) trends approximately east-west and marks the terrane boundary through the inlier (Fig. 3). Five lithological and structural domains are identified within the inlier (Fig. 3). North of the SVLZ is the Northern Slate Belt (NSB) which contains folded siliciclastic meta-sediments. The NSB is overlapped in the east and north by several basalt fields (undated, but probably correlative with Jurassic-Cretaceous lavas elsewhere in the region). The SVLZ is $1-1.5 \mathrm{~km}$ wide and contains a range of locally exposed lithologies, including volcanic lithologies of the Saykhandulaan Valley Formation (SVF) which mainly consist of altered intermediate and felsic lavas. To the south of the SVLZ are several parallel litho-tectonic domains: The High Strain Belt (HSB) contains greenschist grade meta-sandstones and conglomerates deformed into tight-to-isoclinal folds. It is exposed across the full east-west width of the inlier. The Molasse Succession (MS) contains relatively undeformed conglomerates, sandstones and mudstones, and crops out to the south of the HSB. The Oyut Ulaan Volcanic Group (OUVG) contains a wide range of 
volcanic and sedimentary lithologies and defines the southern margin of the inlier. The Oyut Ulaan Intrusion (OUI) cuts rocks of the OUVG in the south east (Fig. 3) corner of the inlier. The inlier is surrounded by basins containing Upper Jurassic to Cretaceous and Quaternary sediments (Figs. 3, 4 and 5; Graham et al., 2001). The inlier contains subdued topography with a maximum relief of $50 \mathrm{~m}$, outcrop quality is variable and in many areas contacts and faults are not exposed.

In this section, the lithologies of each of the domains defined above are described in detail from north to south.

\subsection{Slate belt}

The Northern Slate Belt is a folded, greenschist grade, meta-sedimentary sequence (Figs. 3 and 4). In the north, this sequence is dominated by pelites with well-developed cleavage; the protolith coarsens to the south where fine- to mediumgrained psammites locally dominate. An outstanding feature of this unit is the presence of abundant and volumetrically significant quartz veins.

The main rock type of the NSB is grey pelite, which crops-out in beds 0.5 to 2 metres thick throughout the belt. Graded bedding occurs and locally units exhibit clay drapes and fine-sand lag-bases. The sequence also features sparsely distributed 20 to $50 \mathrm{~cm}$-thick beds of fine- to medium-grained meta-psammite which appear brown on weathered surfaces.

In the west of the NSB where shallower stratigraphic levels are exposed, psammitic lithologies are dominant, featuring up to 1-metre-thick medium-grained units interbedded with relatively thin $20-30 \mathrm{~cm}$ pelitic material. In one section, flame and lobe structures, rip-up clasts and swaley cross stratification occur in the psammite beds and provide younging criteria, however, original sedimentary features were rarely observed outside of psammite dominated areas. 
Lithologies from the southwest corner of the NSB are generally less-deformed, are of a lower metamorphic grade than the rest of the belt, and are sandstone dominated. Lithological logs from the south of the NSB show tabular sandstone bodies of between 10 and $50 \mathrm{~cm}$ thickness, interbedded with mudstone sequences of up-to $1 \mathrm{~m}$ thick. Flame structures, lag bases, rip-up clasts and climbing ripples are present (Fig. 6).

In thin-section, the sand-grade units show different degrees of deformation and metamorphism, from relatively un-cleaved greywacke, to greenshist-grade psammites. The metamorphic fabric consists of re-crystallised quartz grains and a micaceous slatey cleavage. Several samples display a penetrative crenulation cleavage and some have isolated kink bands. Siderite forms a cement and secondary replacement phase. The rocks are generally more calcareous in the northern sector of the NSB; sparse outcrops of a bio-micritic limestone occur near its northern boundary with Cretaceous basin-sediments.

Throughout the NSB, quartz veins cut the succession, the largest of which can be seen from tens of kilometres away and form the highest topographic features in the belt (Fig. 7). The veins trend ENE deviating from the orientation of the regional cleavage by $10-20^{\circ}$. Three generations of veins occur, the oldest are metre-wide veins (Fig. 7b) which are commonly cut by main mega-vein bodies (Fig. 7 a), which are, in turn, cut by later thin-quartz-stockworks. Visible mineralisation is rare, although manganite $(\mathrm{MnO} \cdot \mathrm{OH})$ was observed within zones densely penetrated by 30 $70 \mathrm{~cm}$ wide veins (Fig. 7c). The giant veins and vein zones are found in discrete corridors, with other areas exhibiting little to no veining. Several of the larger tabular veins cut regional fold hinges and some smaller veins have saddle reef morphologies. Sets of veins have both right stepping and left stepping en-echelon morphology (Fig. 
7d). The veins are largest in the southeast of the NSB, where the deepest stratigraphic levels are exposed. The veins are spatially related to coarser lithologies, and at several locations, psammitic beds feature stockworks of quartz veins.

\subsection{Saykhandulaan Valley Lineament Zone}

The SVLZ runs approximately east-west $(085 \mathrm{~N})$ across the inlier, forming a 1 $1.5 \mathrm{~km}$-wide corridor of small isolated hills with little outcrop, between the NSB to the north and HSB to the south (Figs. 3, 5).

Volcanic strata of the Saykhandulaan Valley Formation are best exposed in a ridge that trends 070 , in its western reaches of the SVLZ (see box marking location of outcrop on Fig. 5). An approximately 200m thick sequence of extrusive rocks (Fig. 8) crops out in this ridge. An amygdaloidal trachydacite $(>20 \mathrm{~m})$ is at the base of the sucession. This is overlain by a white rhyolite $(\sim 90 \mathrm{~m})$, which contains sub-planar flow-bands and local zones of intense flow-folding. A variably-brecciated trachyte (70m) lies above this, and another trachyte $(>25 \mathrm{~m})$, featuring dense euhedral feldspar phenocrysts, lies at the top of the sequence. Rhyolites and trachytes crop out at numerous other localities throughout the zone, commonly in prominent ridges with similar 070 trends.

Along the southern edge of the SVLZ, at the foot of some of the steepest and highest topography in the inlier, basic dykes crop-out, both parallel and perpendicular to the lineament.

Brecciated and fractured lithologies are common near the ends of the prominent ridges in the zone. Cataclastic microtextures are seen in thin-section from several samples in these areas. Quartz in some of the felsic lithologies has been extensively recrystallised. 


\subsection{High-Strain Belt}

The HSB is the zone of highest deformation in the inlier (Fig. 5). Its northern margin is the abrupt southern edge of the SVLZ. Directly south of the SVLZ, altered, green, cobble- to boulder-conglomerates form 070 trending ridges comprising the highest topography of the inlier. The metamorphic grade appears locally elevated; some metabasite clasts are entirely altered to amphibolite. Two parallel bands of these higher-grade rocks occur in the north of the HSB, with a narrow band of greenschist-grade meta-clastic rocks between them.

South of the meta-conglomerates, the HSB is comprised of meta-clastic rocks featuring a range of protolith grain sizes from mud to gravel-conglomerate. This part of the belt is similar to the NSB - cleavage is generally dominant, and the rocks are of comparable metamorphic grade to the NSB meta-clastic rocks. However, sandstones and conglomerates are the main protolith here, compared with mudstones in the NSB. Coarse sandstones are widespread, are generally $0.5-2 \mathrm{~m}$ thick and display crossstratification, graded and lenticular bedding, and laminated mudstone tops featuring ripple structures.

\subsection{Molasse Succession}

The Molasse Succession (Fig. 9) is characterised in the west by relatively unmetamorphosed coarse conglomerates, and in the east by interbedded fine sandstones and muds.

Thick channel-based conglomerates mixed with coarse sands (Fig. 9, log a) dominate the molasse succession. The conglomerate beds are poorly sorted, heterolithic, with grain sizes ranging from granule to boulder. The coarse sandstones comprise both a matrix in areas dominated by conglomerate, and the main lithology 
elsewhere, with scattered gravel-grade clasts. Lenticular bed morphologies are common, especially in the conglomeratic units.

In the east of the Molasse Succession, thin, interbedded fine-sandstones and mudstones are prevalent in pairs around $10 \mathrm{~cm}$ thick. The transition from dominantly conglomerate to sandstones and mudstones is shown in Fig. 9, log b. Intraformational mudstone clasts and ripple structures are seen in the coarser bases of some sandstone units (Fig. 9, $\log \mathrm{c}$ ).

\subsection{Oyut Ulaan Volcanic group}

The Oyut Ulaan Volcanic Group comprises 4 distinct formations in the south of the Saykhandulaan Inlier. The OUVG is the most volumetrically significant volcanic succession in the inlier, and its overall stratigraphic thickness exceeds $4000 \mathrm{~m}$. Three of these formations occur in an area of relatively continuous outcrop in the south west of the inlier. The fourth formation is exposed in the east, adjacent to the Oyut Ulaan intrusion (Fig. 5).

The stratigraphically lowest, c.1500m thick, Gurvan Morin Höndiy (Three Horse Valley) Formation is comprised of andesitic lavas interbedded with feldspathic sandstones and up-to $30 \mathrm{~m}$ thick sequences of coarse conglomerates. The conglomerates are heterolithic and feature volcanic, meta-sedimentary and intrusive lithologies. One sandstone sequence contains lycopsid tree-bark impressions and lithified fragments near its base below several tabular sandstone beds. Near the top of the formation a conglomerate features bioclastic limestone clasts and crinoid fragments. Pillow andesites also occur.

The c.2000m thick Shargyn Moghai (Yellow Snake) Formation is above the Gurvan Morin Höndiy Formation. It is comprised of a relatively monotonous succession of basaltic andesites, basaltic trachyandesites and trachyandesites. 
Locally, boulder-grade conglomerates featuring volcanic, meta-sedimentary and intrusive lithologies occur but are laterally discontinuous.

The c.1000m thick Tsagaan Nuruu (White Ridge) Formation is comprised of a number of distinctive 5-10 metre thick felsic lavas, which are blocky and crystalline, and form positive topography, interbedded with ca.60m-thick mudstone and siltstones, which are sparsely exposed. Near its top, between felsic lavas, the formation contains $2-3 \mathrm{~m}$ thick basalt lavas and thinner intervals (25-35m) of sandstone units and black, organic mudstones with plant fragments.

The Yasun Eliy-e (Dead Vulture) Formation is isolated from the rest of the group stratigraphy in the east; it is vertically unconstrained and has a minimum thickness of $1500 \mathrm{~m}$. It forms the host rocks to the Oyut Ulaan intrusion (Fig. 5) and is lithologically similar to the Ghurban Morin Höndiy Formation, but does not display thick conglomerate sequences. Volcanic sandstones and andesitic lithologies are dominant, with some basic lavas in the upper parts of the formation.

The Yasun Eliy-e Formation is the only part of the OUVG to be cut by minor intrusions. In the north, a 1m-wide olivine-phyric basalt dyke trends 130; south of this, in the centre of the area a small dioritic intrusion with a roughly circular surface expression, only $20 \mathrm{~m}$ in diameter, cuts the volcanic-sedimentary succession.

The rocks of the OUVG are relatively un-metamorphosed and un-altered, compared to the rest of the inlier. Wall rock epidotisation locally occurs proximal to faults, fractures and carbonate veins.

\subsection{Oyut Ulaan Intrusion}

The Oyut Ulaan intrusion crops out in the southeast corner of the Saykhandulaan Inlier (Fig. 3). It is elongate, around $10 \mathrm{~km}$ east to west, and $3 \mathrm{~km}$ north to south. To the south, it is bordered by part of the Cretaceous rocks of the 
Zuunbayan basin, on other sides it is in intrusive contact with basement rocks of the Saykhandulaan Inlier. The contact zone is rarely exposed; it is covered by drift in most areas, but the margins of the intrusion are evident on satellite imagery (Fig. 5).

The main intrusion is cut by several dyke swarms, which have a range of compositions and orientations. A series of $1-100 \mathrm{~cm}$ wide pink fine-grained felsic dykes run east-west parallel with the intrusion's long axis. Five- to ten-metre thick dark-green andesite dykes cut the felsic dykes. These are primarily observed in the central area of the intrusion. Their general trend is northwesterly, but they form a radial set striking between 285 and 310 .

The Oyut Ulaan intrusion and the surrounding country rocks host several mineralised features. To the northeast of the main intrusion there is an E-W elongate series of sulphide bearing quartz vein-stockworks within the volcanic country rock. The stockworks are hosted in potassically-altered andesite, and are adjacent to an east-west trending dyke. A second mineralised feature occurs along the SE margin of the intrusion within a zone of margin-parallel quartz veins and wall rock screens. This prospect consists of hard, silicified pods, surrounded by altered wall-rock that has a visibly obvious malachite presence. A tourmaline breccia-pipe cluster forms a series of rounded black hills within the intrusion. These hills are a topographic high point and appear in stark contrast to the pink-white granite landscape surrounding them. The tourmaline breccia pipes are spatially associated with minor pegmatite bodies. Further discussion of the mineralisation is beyond the scope of this paper and is being prepared for separate publication.

\subsection{Mesozoic and Cenozoic cover sequences}

Mesozoic basaltic lavas lie unconformably on the Northern Slate Belt. The largest areas of lava are on the northern margin of the NSB, and to the east near the 
junction between the NSB, the eastern basin and the Saykhandulaan Valley Lineament Zone (Figs. 3 and 4). The lavas dip gently to the south and have layers between 5 and $10 \mathrm{~m}$ thick, forming an extensive trap-topography. Several smaller basalt remnants sit on the NSB in various locations in the west. Geodes and amygdales are abundant within the Mesozoic lavas.

In several localities near the inlier, partially lithified Cretaceous sediments are deformed and exposed. The best example of this is on the southern margin of the basin which lies to the east of the NSB. Throughout the inlier interpreted faults that bound various lithological domains are generally hidden beneath recent alluvial cover sequences.

\section{Provenance data}

Thirteen samples from the Northern Slate Belt, High Strain Belt and Molasse Succession were point-counted for sandstone provenance. Several samples that were of an appropriate grain size for provenance work were discarded from this survey due to metamorphic grade and alteration. Five hundred points were counted for each thin section. The results are plotted on a quartz-feldspar-lithics ternary diagram (fig. 10) and indicate that sediments of the NSB were derived from a cratonic source, whereas sediments in the HSB and MS were derived from volcanic arc domains, at different stages of evolution.

\section{Geochemical data}

Seventeen volcanic samples from the Saykhandulaan Valley Formation were analysed using standard spectrometry techniques at the University of Leicester. The formation contains a sequence of dominantly high-K, calc-alkaline lavas with compositions that range from trachydacites and trachytes to rhyolites (Fig. 11). The bulk of samples are rhyolites. Harker variation diagrams (Fig. 12) illustrate some key 
geochemical characteristics and trends of the Saykhandulaan Valley Formation. MgO and $\mathrm{CaO}$ both fall with increasing $\mathrm{SiO}_{2}$ and have distinctive changes in their geochemical gradient, $\mathrm{Al}_{2} \mathrm{O}_{3}$ and $\mathrm{Fe}_{2} \mathrm{O}_{3}$ decrease linearly with increasing $\mathrm{SiO}_{2}$, these features suggest early mafic and feldspar controlled fractionation. $\mathrm{Rb}, \mathrm{Ba}$ and $\mathrm{Sr}$ are scattered due to their post-emplacement mobility. $\mathrm{K}_{2} \mathrm{O}$ and $\mathrm{NaO}_{2}$ values show more scatter than other results, however, trends are discernible; increasing $\mathrm{K}_{2} \mathrm{O}$ and decreasing $\mathrm{NaO}_{2}$ with $\mathrm{SiO}_{2}$ is suggestive of albite fractionation. $\mathrm{Ba}$ and $\mathrm{Sr}$ values suggest that the Saykhandulaan Valley Formation may have evolved by fractional crystallisation of feldspars and biotite. The liquid line of descent originates from a source chemically similar to the Oyut Ulaan granite (Fig. 13).

Eight analyses from known stratigraphic positions (Fig. 7) show evidence for systematic variations in composition. Plots of major and trace elements vs relative stratigraphic position show that there are consistent variations for several elements over time (Fig. 14). $\mathrm{K}_{2} \mathrm{O}, \mathrm{Sr}$ and $\mathrm{Rb}$ act compatibly, whereas the sequence becomes more enriched in Y. Other elements do not show discernible trends.

Multi-element normalised diagrams for the Saykahndulaan Valley Formation (Fig. 15) show strong negative anomalies for $\mathrm{Nb}, \mathrm{Rb}, \mathrm{Sr}, \mathrm{P}$ and $\mathrm{Cr}$ and positive anomalies for $\mathrm{Th}, \mathrm{Ba}$ and $\mathrm{Zr}$. The negative $\mathrm{Nb}$ anomaly and high ratio of low-fieldstrength-elements (LFSE) to high-field-strength-elements (HFSE) are both features typical of subduction related volcanism (Fig. 15; Saunders et al., 1980; Wilson, 1989). The negative $\mathrm{Sr}$ and $\mathrm{Rb}$ anomalies may be linked to feldspar and biotite fractionation. The $\mathrm{Ba}, \mathrm{Zr}$ and $\mathrm{Th}$ positive anomalies may be linked to cumulus potassic feldspar and zircon.

Field observations and petrographic analysis indicate widespread silicification in the lavas of the Saykhandulaan Valley. Geochemical results support this 
observation; silica values between 76 and $80 \%$ are recorded for three samples (Fig. 11).

Graphical comparison of the trace element composition of an altered rock with its least-altered-equivalent allows the quantification of metasomatic processes that affected the altered sample (Grant, 1986). It is assumed that the sample identified as least-altered-equivalent has not undergone metasomatic alteration, and that, in the altered sample, $\mathrm{Zr}, \mathrm{Y}$, and $\mathrm{Nb}$ have remained relatively immobile. Trace element results for the two samples are plotted against each other, and a line of best fit, the isocon, is drawn through $\mathrm{Zr}, \mathrm{Y}$ and $\mathrm{Nb}$ points.

Isocon diagrams (Fig. 16; Grant, 1986) of Saykhandulaan Valley rocks show that altered samples have undergone metasomatic enrichment of $\mathrm{Rb}$, $\mathrm{As}$ and $\mathrm{Ba}$. Zirconium, $\mathrm{Y}$ and $\mathrm{Nb}$ (along with other elements that plot on or near the isocon) have lower values in the altered samples than in the least-altered-equivalents; this suggests mass-gain has occurred, diluting the initial concentrations of these elements. This provides geochemical evidence that supports the interpretation that volumetrically significant secondary silicification has occurred. Whilst post-emplacement metasomatic mobility of trace elements may adversely affect petrogenetic analysis (e.g. Fig. 13), silicification may have modified the position of samples on the TAS petrological discrimination diagram, causing compositions to plot in more evolved fields (Fig. 11).

The Saykhandulaan Valley Formation is chemically similar to the Tsagaan Nuruu Formation of the OUVG (Figs 11, 15). It also overlaps with the more silicic parts $(>60 \%)$ of the Gurvan Morin Höndiy Formation (Fig. 11). Further discussion of the detailed geochemistry of the OUVG is beyond the scope of this paper, and is being prepared for separate publication. 


\section{Structural data}

The strike of the dominant structural grain in the Saykhandulaan Inlier varies from 090 in the southwest, to 050 in the southeast and in the NSB. Folding occurs throughout the inlier and each litho-tectonic domain has a characteristic fold style. Cleavage is variably developed; the HSB and NSB display a widespread penetrative cleavage, whilst the MS, OUVG and rocks of the SVLZ are uncleaved or only affected by spaced cleavage.

At first-order, the NSB consists of regional-scale west-plunging folds, the limbs of which form a 'Z' across the belt (Fig. 4). Second-order folds occur on a scale of 10-100 metres (Fig. 17). These folds plunge to both the east and west. Vergence varies through the zone, appearing to fan around first-order folds, which are upright.

The HSB features tight-to-isoclinal steeply-inclined folds which plunge to the east and west and verge south (Fig. 18). Fold closures were not directly observed in the field, however some apparent closures and low angle truncation can be identified on the aerial photograph in Fig. 5, and younging criteria prove the existence of fold hinges (Fig. 18). Other folds were observed on Landsat imagery at the eastern end of the HSB.

Bedding readings from the MS show gentle, upright, open folds (Fig. 9). Bedding becomes slightly steeper towards the northern boundary with the HSB (see cross section on fig. 9).

The folds in the OUVG are the most recognisable on the ground. The three stratigraphically contiguous formations crop-out in the west in a first-order westplunging syncline. The Tsagaan Nuruu Formation crops-out in the centre of this syncline (Fig. 19) and similar-style $\mathrm{M}-\mathrm{W}$ folds in rhyolite lavas form positive topography. The northern limb of the syncline is truncated by east-west oriented 
faults. Poles to bedding planes (Fig. 19) trace the profile-plane of this syncline. Folds in OUVG have a slightly different trend from folds elsewhere in the inlier - striking around $090(\mathrm{E}-\mathrm{W})$ and plunging west.

Well developed axial planar cleavage characterises pelitic lithologies in both the NSB and HSB. The different vergence directions of the NSB is reflected in the wide range of cleavage orientations shown in fig. 17. Cleavage-bedding intersection lineations which are a proxy for fold hinges, plunge both to the east and west (Fig. 17, stereoplot 2). Cleavage is dominant in the south-east corner of the NSB, and is deformed into tight, upright $\mathrm{F}_{2}$ folds. Cleavage in the HSB is sub-parallel to bedding, and is steep and dominantly north dipping (Fig. 18, stereoplot 2). The coarse and relatively fresh lithologies of the MS do not contain a well developed cleavage, but where spaced cleavage was observed, it is near vertical and shows little variation compared to other domains (Fig. 9).

Remote sensing imagery reveals many faults that cut the Saykhandulaan Inlier, however, because of the near peneplain relief of the entire inlier, comparatively few faults have exposed surfaces with visible kinematic indicators. One of the bestexposed faults is a brittle thrust that defines the northern edge of the HSB in the east, which has partially consolidated upturned Mesozoic sediments in the footwall (Fig. 20c). Oblique-slip faults are exposed near the southern margins of the molasse succession. Both of these examples relate to post-Cretaceous fault movements at the boundary between Palaeozoic strata and Cretaceous basin sequences; although the faults themselves could have formed earlier, and been subsequently reactivated. Within the Saykhandulaan Valley Lineament, north-dipping thrust faults crop-out in the silicified rhyolitic units of the Saykhandulaan Valley Formation (Fig. 20a). Striations indicating dip-slip movement are locally observed (Figs 21b, 22a). Strike- 
slip faults are not exposed at the surface and so those recorded in the field were inferred to be vertical because they from linear depressions and offset contacts and lithologies (Figs 21b-d).

Inferred normal faults define the eastern and western edges of the inlier. In the northeast, a normal fault-bound Cretaceous basin lies along strike from the NSB. The Cretaceous basin is bordered to the south, by the HSB. Where the Saykhandulaan Valley Lineament Zone joins the basin, there are a number of fault bound troughs partially covered by onlapping Cretaceous sediments. The basement to these small depo-centres appears to be faulted blocks of the HSB (Fig. 5).

\section{Discussion}

The Palaeozoic geological evolution of the Saykhandulaan Inlier is dominated by siliciclastic sedimentation in a wide variety of environments, with erupted sequences of volcanic rocks, arc-related plutonism and contractional deformation. Although major questions remain about the overall geological evolution of Southeast Mongolia, the lithological and structural data presented here provide the basis for the first detailed interpretation of basement rocks of Southeast Mongolia, and their terrane context.

The original depositional environment of the Northern Slate Belt pelitic and psammitic rocks is interpreted to represent a shelf-to-tidal shallowing-environment. The stratigraphically lowest parts of the NSB are interpreted to be exposed in the southeast, in the core of the west-plunging first-order anticline (Fig. 17). The dominant protolith is mudstone, in upward-fining turbiditic sequences suggesting deep marine sedimentation. Coarser units and sedimentary features in the southwest, at higher stratigraphic levels, may represent a prograding fluvial or deltaic environment with the influence of both fluvial and wave processes. Flame structures 
in at the base of medium-grained sandstone units suggest loading onto soft, wet mud, and rapid accumulation of sediment. Swaley cross stratification suggests a Palaeodepth of the upper zone of storm-wave influence (Tucker, 1991). The uppermost parts of the stratigraphy are exposed in the northwest, in the first order syncline (Fig. 17). Psammitic units from throughout the NSB record a cratonic provenance (Fig. 10). The NSB is considered part of the Gobi Altai terrane, which is bordered to the north by passive margin and cratonic terranes (Fig. 1; Badarch, 2002). It is thus likely that the cratonic source of the sediments that formed the protoliths to the NSB was in this northern region.

The volcanic rocks of the Sakhandulaan Valley Formation have undergone considerable metasomatic alteration, related to fluids moving in the Saykhandulaan Valley Lineament Zone. The alteration makes accurate interpretation of primary geochemical signatures problematic though not impossible. Multi-element plots of trace-elements suggest the succession is volcanic-arc related, and it is chemically similar to the upper parts of the OUVG. It has, however, been more extensively deformed and tectonised than the OUVG, and the thickness of the succession suggests it represents a far less extensive history of volcanism.

The HSB is proximal to the NSB and of a relatively similar metamorphic grade and protolith. However, the sediments that formed the HSB protolith have a dissected continental arc provenance and thus are probably south-derived (Fig. 10). Deformation obscures original sedimentary structures in most areas, but locally younging evidence was observed. The coarse-conglomerate parts of the HSB, near the Saykhandulaan valley, are interpreted to represent lower sections of the stratigraphy than the more voluminous sand- and granule-grade meta-clastic rocks to the south. The grain size range, cross-stratification and lenticular bedding suggest a 
sand-dominated braided river system as the depositional environment for the bulk of the HSB.

The Yasun Eliy-e Formation, though not in direct contact with the rest of the OUVG, is interpreted to be the oldest volcanic formation as it is the least evolved. It has lithological similarities to and geochemical overlap with the Gurvan Morin Höndiy Formation, which is at the base of the contiguous volcanic stratigraphy in the west (Fig. 5).

In the Ghurvan Morin Höndiy Formation, various granite clasts in fanglomerate successions that are intercalated with the volcanics suggest older, exhumed arc-crust was eroded during the early stages of OUVG volcanicity. It seems likely that this partially dissected arc could be the same source as that for the sediments that were the protolith to the HSB. The difference in grain size may suggest that the depositional environment of the HSB-protolith was further from the eroding source than was the OUVG. Pillow andesites and lycopsid tree bark in sandstone suggests a shallow marine to coastal terrestrial palaeo-environment during early stages of the Oyut Ulaan volcanism.

The Shargyn Moghai Formation is almost entirely dominated by thick trachyandesitic sheets with little intervening material, this indicating probable high effusion rates.

In the Tsagaan Nuruu Formation, the succession is mainly composed of fine- to medium-grained volcaniclastic deposits. It is unclear whether the felsic lavas that punctuate this sequence are extrusive or hypabyssal in nature. They appear to have had a very large areal extent for felsic lavas, and were either particularly hot and of low viscosity on extrusion; or were injected into the sediments laterally. Sediments in the upper parts of the succession also suggest a marine marginal environment. 
The poorly-sorted conglomerates of the MS represent a coarse-grained braidedriver system which drained the OUVG. Fine sand and mudstone sequences may represent flood-related overbank sequences, or cyclic lake-sedimentation. The MS occurs unconformably on rocks of the HSB. Provenance data suggest the MS sediments were derived from an undissected arc of continental to intra-oceanic affinity (Fig. 10). It is interpreted to be the youngest lithology of the inlier because it lies unconformably on the HSB and is un-metamorphosed and less deformed.

At least four deformation events are recorded in the Saykhandulaan inlier. D1 is expressed in the NSB as a regional folding and cleavage forming event under lower greenschist grade metamorphic conditions. D1 folds generally trend ENE. Few Palaeozoic thrust surfaces were directly observed, however a few thrusts are tentatively interpreted from metamorphic breaks and fold asymmetry. The upright first-order folds of the NSB feature several zones of abrupt vergence changes, these are interpreted to be the effects of either blind-thrusts or thrusts that break the surface, but are obscured by drift (summary section; Fig. 17). South of the NSB unambiguous evidence for D1 was not observed.

D2 is a second contractional event, which has affected the entire inlier. Evidence for D2 consists of F2 folds of S1 cleavage, local crenulation cleavage and kink banding in the NSB. Quartz veins in the NSB postdate the formation of the $\mathrm{S}_{1}$ cleavage, and may have been emplaced parallel to cleavage planes during D2. The veins are spatially related to psammite units, which may have deformed in a brittle manner compared to surrounding pelites, providing conduits for hot $\mathrm{SiO}_{2}$-rich solutions. Intense folding and greenschist grade metamorphism within the HSB may have occurred during D1 and/or D2; no F2 folds of cleavage were identified. 
South of the NSB, the Saykhandulaan Valley Lineament Zone is an important topographic and structural boundary, separating arc related rocks to the south, from basin sediments in the north. The zone itself is a two-kilometre wide corridor of distributed cataclastic deformation, discrete faulting and abundant silicification. It is interpreted that the SVLZ may represent a south-dipping thrust zone, which brought the highest-grade rocks of the area (the HSB) to the surface during D1 and/or D2, entraining slivers of the Saykhandulaan Valley Formation in its base. Some minor north-dipping thrust surfaces are seen in the SVLZ, these are interpreted to be backthrusts.

The Molasse Succession and Oyut Ulaan Volcanic Formation have undergone the least deformation. The Molasse Succession has fold orientations that match those of the underlying HSB, but the folding is far less intense. Orientations of folds in the OUVG suggest it may have been affected by N-S shortening in contrast to the NNWSSE directed compression seen in the rest of the inlier (Figs. 9, 19). Folding in the OUVG is interpreted to have occurred during D2 because the sequence lacks cleavage and evidence for metamorphism which are typical of D1 deformation to the north. Gentle folding in the MS is interpreted to be a late stage expression of D2.

The Oyut Ulaan intrusion, which is emplaced in the lowermost and leastevolved parts of the OUVG, is elongate in a direction parallel to the axial trace of folds in the OUVG. The granite may have been affected by the same N-S directed shortening as the OUVG, but more evidence is needed to confirm this. Preliminary unpublished $\mathrm{U}-\mathrm{Pb}$ zircon dates indicate that the Oyut Ulaan intrusion has a midCarboniferous emplacement age (publication in prep., Blight et al.). This is consistent with regional evidence for Devonian-Carboniferous arc magmatism throughout southern Mongolia (Lamb and Badarch, 2001). 
D3 represents Jurassic-Cretaceous crustal extension widespread in the region (Graham et al. 2001). Normal faults that cut the inlier and bound Cretaceous basins around the inlier are likely to have formed during D3.

Some strike slip faults that cut the inlier including the SVLZ cut all older structures and are therefore suspected of being the youngest faults in the region, and represent a fourth deformation event, D4 . Recorded sinistral minor faults, and major faults interpreted to have sinistral offsets trend 030-070, interpreted dextral antithetic shears trend around 160 (Fig. 22). Orientations of faults recorded in the field, and interpreted on satellite imagery (Fig. 22) suggest a sinistral Riedel-shear deformation regime during the Late Cretaceous or Tertiary. These fault displacements may have been co-genetic with brittle sinistral movements on the nearby Zuunbayan Fault (Fig. 1(Lamb et al., 1999) during the Late Cretaceous or Tertiary.

The recognition that the Saykhandulaan inlier contains a southern volcanic arc complex and a northern deformed and metamorphosed marine basin assemblage, sheds light on the regional scale tectonic events that were responsible for crustal growth in southeast Mongolia. The shortening and metamorphism within the NSB indicates closure and inversion of the basin between an arc to the south and a continental block to the north. No evidence for subduction, ophiolite obduction or accretionary prism development exists during closure of the NSB basin. Therefore, it is unlikely that the NSB basin was ever floored by oceanic crust and instead is interpreted to have been ensialic. The polarity of subduction beneath the arc-complex in the southern inlier was therefore probably north directed, consistent with other regional interpretations within the $\mathrm{CAOB}$ of Palaeo-Asian Ocean closure (Fig.2; Şengör and Natal'in 1996; Badarch et al. 2002). Apart from local en echelon-vein arrays in the NSB, little evidence was observed for the Palaeozoic large-scale dextral 
movements postulated in the models of both Şengör and Natal'in (1996) and Badarch et al. (2002). Any major strike-slip displacements within the inlier were probably focused along the SVLZ and adjacent HSB, which represent the composite terrane boundary between the Gobi Altai and Mandalovoo terranes.

\section{Conclusions}

The Saykhandulaan inlier provides a window into the Palaeozoic evolution of the northern margin of the Palaeo-Asian Ocean in southeast Mongolia. Five major lithotectonic domains are distinguished that help elucidate the crustal evolution in the region. More than four thousand metres of volcanic rocks with arc geochemical signatures are documented, and the intrusion of the mineralised Oyut Ulaan granite suggest subduction-related magmatism. Two major deformation events are recorded related to basin closure, inversion and accretion of the Mandalovoo arc-terrane. Basin closure involved regional scale folding and greenschist grade metamorphism. Following terrane accretion and cessation of subduction, crustal extension and strikeslip faulting have further modified the crustal architecture of the inlier. The results presented here provide a useful framework for understanding the crustal evolution of adjacent regions within the southeast Gobi mineral belt.

\section{Acknowledgements}

Research reported in this article was supported by the National Environmental Research Council, UK, the Society of Economic Geologists, the University of Leicester and Ivanhoe Mines Ltd. We thank G. Badarch of the Institute of Geology and Mineral Resources, Mongolian Academy of Sciences, for technical support; Simon Crockford for excellent fieldwork assistance; and Helen Crowther for critical reviews of parts of this manuscript. 


\section{Figure Captions}

\section{Fig. 1}

Tectonostratigraphic terrane map of South East Mongolia, after Badarch et al. (2002). Terranes discussed in this study are labelled in bold. Location and offset sense of Zuunbayan Fault after Lamb et al. (1999). Location of Solonker Suture after Xaio et al. (2003) Location of terrane boundaries in China not shown because of uncertain correlations there. Inset maps show regional political boundaries (top) and locations of Precambrian cratons and terrane collage comprising Central Asian Orogenic Belt (CAOB) after Şengör and Natal'in (1996) and Helo et al. (2006); bottom) .

\section{Fig. 2}

Two interpretations of tectonic setting in southeast Mongolia in DevonianCarboniferous time.

a) Early Carboniferous palaeotectonic reconstruction of the craton-proximal section of the Tuva-Mongol arc, after Şengör and Natal'in (1996). Growth of the arc takes place via accretion above northward dipping subduction zone, and strike-slip duplication along the arc front. The South Mongolian Unit (marked SMU) is a subduction-accretion complex, which represents the majority of the Palaeozoic crustal growth in southeast Mongolia. Box A shows approximate position of the study area.

b) Simplified reconstruction of Devonian-Carboniferous terrane positions in South Mongolia, after Badarch et al. (2002). The diagram shows two northward dipping subduction zones beneath parallel E-W island arcs. The Mandalovoo (MOV) and Gurvansayhan $(\mathrm{GV})$ terranes represent laterally contiguous sections of the same arc. Box A shows approximate position of the field area (Fig 3). 
Fig. 3

Landsat image of Saykhandulaan Inlier, location shown in Fig. 1. Lithotectonic domains marked: NSB - Northern Slate Belt; SVS - Saykhandulaan valley sequence; HSB - High-strain steep belt; MS - Molasse Sequence; OUVG - Oyut Ulaan Volcanic Group; OUI - Oyut Ulaan intrusion. Areas outside of marked lithotectonic domains contain Mesozoic-Cenozoic sedimentary cover sequences and lavas. Locations of Figs. 4 and 5 shown.

Fig. 4

Interpreted Landsat image of the Northern Slate Belt. Dominant NE-SW structural grain emphasised with fine lines. Interpreted faults shown with heavy dashed lines. Locations of transect segments shown.

\section{Fig. 5}

a. Aerial photograph of the southern part of the field area. Location of Fig. shown in Fig. 3. Notice dominant ENE-WSW grain.

b. Interpretation of Fig. 5a showing litho-tectonic units: HSB - High strain steep belt, MS - Molasse Sequence; OUVG - Oyut Ulaan Volcanic Group; OUI Oyut Ulaan intrusion. Dominant structural grain marked with fine lines. Faults, observed and interpreted, marked with thicker lines. Locations of transect lines shown.

Fig. 6

a-f) Stratigraphic logs from southern zone of Northern Slate Belt. Coarser lithologies occur in south of belt where psammitic bands are thicker and more widespread. g) fine grained psammite and pelite interbeds similar to $\log$ c. h) flame structure preserved in relatively un-metamorphosed sandstone and mudstone from log f. 
Fig. 7

a) Map of large en-echelon quartz vein array visible in 'a' (location noted on Fig. 4) with arrows to show interpreted dextral shear sense. b) View NE of major quartz vein outcrop. c) View SE from top of vein outcrop hill, many more large veins in distance d) View NE of metre-scale quartz veins.

Fig. 8

Stratigraphic columns for Saykhandulaan Valley Volcanic Formation, grain size and lithological features shown. Samples taken for analysis marked. Inset map of Saykhandulaan Valley Volcanic Formation outcrop (see Fig. 5 for location). Fault orientations and sense of movement inferred from topographic features and contact offsets.

Fig. 9

Lithological logs and photographs from Molasse Sucession showing vertical transition from conglomerates to intercalated fine-sand and mudstones. Photograph of horizontal intercalated sandstone and mudstone beds Logs and photograph located on inset transect line. Stereoplot of MS structural data Location of transect shown on Fig. 5

Fig. 10

Sandstone compositional data from Northern Slate Belt (NSB), High Strain Belt (HSB) and Molasse Succession (MS). Provenance fields from Marsaglia and Ingersoll (1992).

\section{Fig. 11}

Total Alkalis Silica (TAS) diagram after Le Bas et al. (1986) for Saykhandulaan Valley Formation Volcanic rocks. Fields indicate general compositions of Oyut Ulaan Volcanic Group rocks by formation. 
Fig. 12

Harker variation diagrams of $\mathrm{Al}_{2} \mathrm{O}_{3}, \mathrm{Fe}_{2} \mathrm{O}_{3}, \mathrm{MgO}, \mathrm{CaO}, \mathrm{Rb}, \mathrm{Ba}, \mathrm{Sr}, \mathrm{K}_{2} \mathrm{O}, \mathrm{Na}_{2} \mathrm{O}$ versus $\mathrm{SiO}_{2}$. Fields indicate general composition of Gurvan Morin Höndiy Formation (with $\mathrm{SiO} 2$ values $>60 \%$ ) and Tsagaan Nuruu Formation.

\section{Fig. 13}

Log $\mathrm{Ba}$ versus $\log \mathrm{Sr}$ diagram for Saykhandulaan Valley Formation Volcanic rocks showing fractionation with apparent feldspars and biotite control. Inset fractional crystallisation vectors for plagioclase, K-feldspar, biotite, horneblende, orthopyroxene, clinopyroxene using partition coefficients for rhyolitic liquids from Rollinson (1993).

\section{Fig. 14}

Relative stratigraphic position versus $\mathrm{Na}_{2} \mathrm{O}+\mathrm{K}_{2} \mathrm{O}, \mathrm{Y}, \mathrm{Sr}, \mathrm{Rb}$ for Saykhandulaan Valley Formation Volcanic rocks.

\section{Fig. 15}

Multi-element diagram of trace elements for Saykhandulaan Valley Formation volcanic rocks. Fields indicate general composition of Gurvan Morin Höndiy Formation (with $\mathrm{SiO} 2$ values $>60 \%$ ) and Tsagaan Nuruu Formation.

\section{Fig. 16}

Isocon diagrams of altered samples versus least-altered-equivalents for Saykhandulaan Valley Formation Volcanic rocks.

\section{Fig. 17}

Individual structural transects through Northern Slate Belt and combined summary section incorporating all lines. Bedding traced by form lines showing folds. Map shows location of transect line segments. Stereoplot 1. - NSB poles-to-beddingplanes on lower hemisphere equal-area stereoplot. Stereoplot 2 - NSB poles-to- 
cleavage-planes on lower hemisphere equal-area stereoplot. Summary section demonstrates kilometre scale first order folding within NSB.

\section{Fig. 18}

Transect line through HSB Bedding and cleavage traced by form lines. Interpreted folds shown by dashed lines. Location of transect shown on Fig. 5. Stereoplot 1) HSB poles-to-bedding-planes on lower hemisphere equal-area stereoplot. Stereoplot 2) HSB poles-to-cleavage-planes on lower hemisphere equalarea stereoplot. Photo a. shows flattened clasts and spaced cleavage in metaconglomerate of HSB, pen for scale.

\section{Fig. 19}

Transect line through Oyut Ulaan Volcanic Group, upper parts of Shargyn Moghai Formation (to left) comprise north limb of regional syncline that dips to south under Tsagaan Nuruu Formation which is deformed into m-w folds in core of syncline (to right). Location of transect shown on Fig. 5. Stereoplot 1. - OUVG poles-tobedding-planes on lower hemisphere equal-area stereoplot.

\section{Fig. 20}

a) Backthrust zone in Saykhandulaan Valley Formation silicified rhyolite. View to west, hammer for scale. b) Detail of thrust surface showing down-dip slickenlines, hammer for scale. c) High Strain Belt greenschist-grade meta-conglomerates (left) thrust over partially consolidated near-vertical dipping Cretaceous sediments (right) View to west.

\section{Fig. 21}

a) Orientations of thrust faults - (unbroken line) and minor back-thrusts - (dashed line) from the Saykhandulaan Valley Lineament Zone. Striations on fault surfaces 
(crosses) indicate dominant dip-slip motion. b) Oblique-slip and strike-slip faults from back-thrusted zone in Saykhandulaan Valley. Striations on fault surfaces indicate dominant strike-slip motion. c) Orientations of brittle faults with apparent sinistral offsets from the whole inlier. d) Orientations of brittle faults with apparent dextral offsets from the whole inlier.

\section{Fig. 22}

Landsat image of Saykhandulaan Inlier. Interpreted and measured faults from inlier shown with movement sense. Inset sinistral Riedel-shear model shows predicted orientations of major and antithetic shears and normal faults. The orientation of Mezozoic regional sinistral movements compares well with array of strike- and oblique-slip faults identified in this study.

\section{Fig. 23}

Evolutionary model to illustrate the development of the Saykhandulaan Inlier from the Devonian to the end of the Permian.

a. Deposition of the protolith to the NSB occurs in a back-arc basin fed by sediments from the passive margin of a craton to the north. In the south, a rifted continental arc is eroded and provides sediments for the protolith to the HSB.

b. Volcanism continues, sediments that compose the HSB protolith are buried and N-S compressive deformation begins (D1) as back-arc basin closes.

c. D1 strain is focussed in the HSB, which is tightly folded at depth. Thrusting ensues, with the main thrust zone exploiting the Saykhandulaan Formation as a brittle décollement. The HSB is thrusted over the NSB which displays upright folds, and discrete zones of northern vergence, interpreted to be related 
to further south dipping thrusts. The Saykhandulaan Formation forms a duplex in the thrust zone. To the south, the lower lavas of the OUVG are erupted and interbedded with conglomerates derived from the dissected old continental-arc crust.

d. A second deformation with similar principle stress axes folds the newly formed OUVG and the S1 cleavage in the NSB is folded proximal to the Saykahdulaan Thrust. Back-thrusting occurs in the thrust zone and cuts the HSB. Fluid flow along the Saykhandulaan thrust silicifies the lithologies within the zone, and is focussed in giant quartz veins in parts of the NSB. To the south the Oyut Ulaan intrusion is emplaced and the OUVG is uplifted and eroded.

e. Some oblique slip motion occurs on faults formed parallel to steep cleavage domains in the NSB and HSB. Parts of the OUVG are displaced laterally out of section. The OUVG forms the sediment source for intermontane molasse basins to its north. Subsequently molasse is gently folded and acquires a vague space cleavage. 


\section{References}

Badarch, G., Cunningham, W. D., Windley, B. F., 2002. A new terrane subdivision for Mongolia: Implications for the Phanerozoic crustal growth of Central Asia. Journal of Asian Earth Sciences, 21: 87 - 110.

Barry, T.L. and Kent, R.W. (Editors), 1998. Cenozoic magmatism in Mongolia and the origin of Central and East Asian basalts. American Geophysical Union, Washington, DC, 347-364 pp.

Cunningham, W.D., 1998. Lithospheric controls on late Cenozoic construction of the Mongolian Altai. Tectonics, 17(6): 891-902.

Graham, S.A. et al., 2001. Sedimentary Record and Tectonic Implications of Mesozoic Rifting in Southeast Mongolia. GSA Bulletin, 113(12): 1560-1579.

Grant, J.A., 1986. The Isocon Diagram: A Simple Solution to Gresens' Equation for Metasomatic Alteration. Economic Geology, 81: 1976-1982.

Helo, C. et al., 2006. Geochemical signature of palaeozoic accretionary complexes of the Central Asian Orogenic Belt in southern Mongolia, constraints on arc environments and crustal growt. Chemical Geology, 227: 236-257.

Lamb, M.A., Hanson, A.D., Graham, S.A., Badarch, G. and Webb, L.E., 1999. Leftlateral sense offset of upper Proterozoic to Paleozoic features across the Gobi Onon, Tost, and Zuunbayan faults in southern Mongolia and implications for other Central Asian faults. Earth and Planetary Science Letters, 173(3): 183194.

Le Bas, M.J., Le Maitre, R.W., Streckeisen, A. and Zanettin, B., 1986. A chemical classification of volcanic rocks based on the total alkali-silica diagram. Journal of Petrology, 27(3): 745-750. 
Marsaglia, K.M. and Ingersoll, R.V., 1992. Compositional trends in arc-related, deepmarine sand and sandstone; a reassessment of magmatic-arc provenance. Geological Society of America Bulletin, 104: 1637-1649.

Meng, Q., Hu, J., Jin, J., Y., Z. and Xu, D., 2003. Tectonics of the late Mesozoic wide extensional basin system in the ChinaMongolia border region. Basin Research, 15(3): 397-415.

Perello, J. et al., 2001. Oyu Tolgoi, Mongolia; Siluro-Devonian porphyry Cu-Au(Mo) and high-sulfidation $\mathrm{Cu}$ mineralization with a Cretaceous chalcocite blanket. Economic Geology, 96(6): 1407-1428.

Rollinson, H., 1993. Using geochemical data: evaluation, presentation, interpretation. Longman, $352 \mathrm{pp}$.

Saunders, A.D., Tarney, J. and Weaver, S.D., 1980. Transverse geochemical variations across the antarctic penninsula: implications for the genesis of calcalkaline magmas. Earth and Planetary Science Letters, 46: 344-360.

Sengor, A.M.C. and Natal'in, B.A., 1996. Palaeotectonics of Asia: fragments of a synthesis. In: A. Yin and M. Harrison (Editors), The Tectonic Evolution of Asia. Cambridge University Press, Cambridge, pp. 486-640.

Tucker, M.E., 1991. Sedimentary Petrology: an introduction to the origin of sedimentary rocks. Blackwell Science, Oxford, $260 \mathrm{pp}$.

Watanabe, Y. and Stein, H.J., 2000. Re-Os ages for the Erdenet and Tsagaan Suvarga porphyry $\mathrm{Cu}-\mathrm{Mo}$ deposits, Mongolia, and tectonic implications. Economic Geology, 95(7): 1537-1542.

Wilson, M., 1989. Igneous petrogenesis; a global tectonic approach. Unwin Hyman, London, 466 pp. 
Xiao, W., Windley, B.F., Hao, J. and Zhai, M., 2003. Accretion leading to collision and the Permian Solonker suture, Inner Mongolia, China: Termination of the central Asian orogenic belt. Tectonics, 22(6).

Xiao, W. et al., 2004. Palaeozoic accretionary and convergent tectonics of the southern Altaids: implications for growth of Central Asia. Journal of the Geological Society of London, 161: 339-342. 


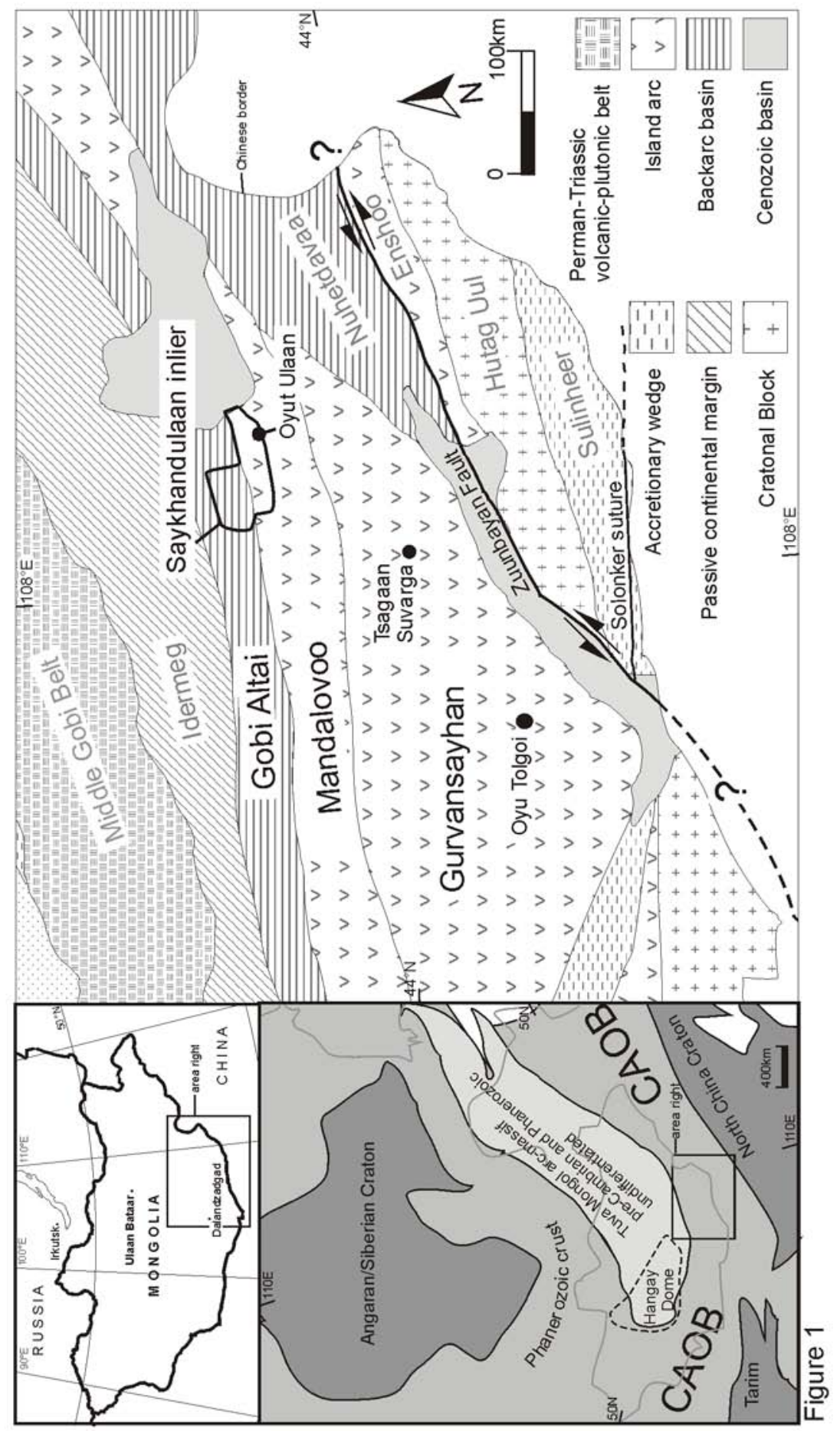




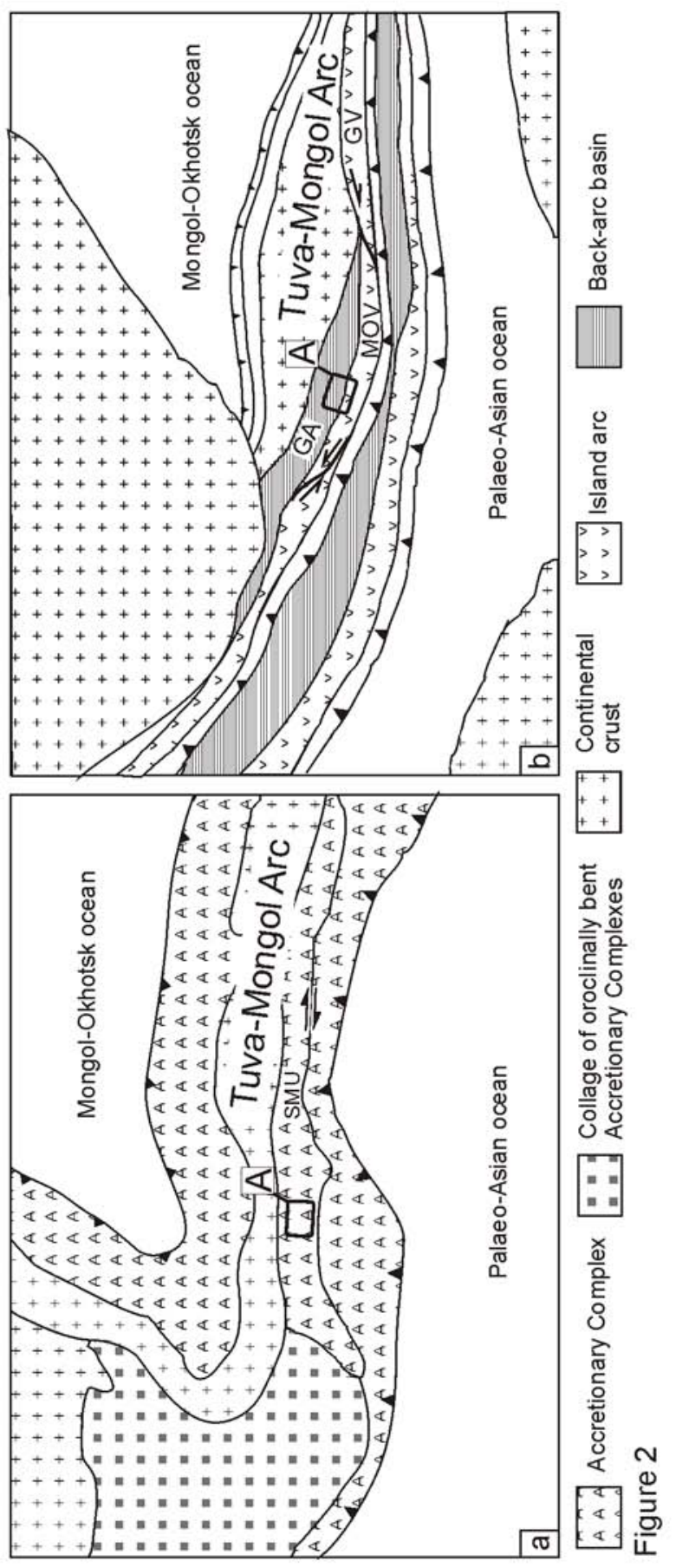




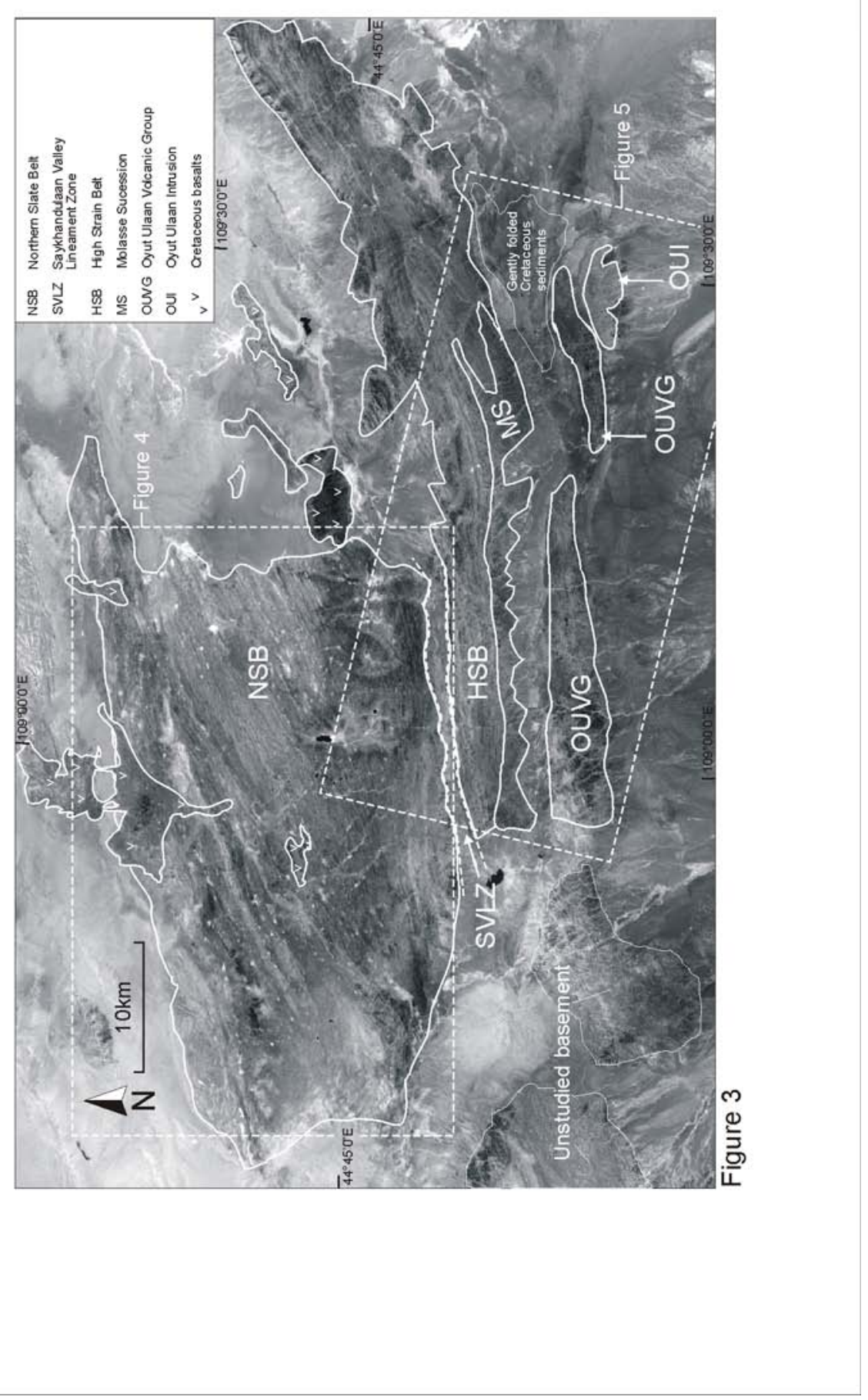




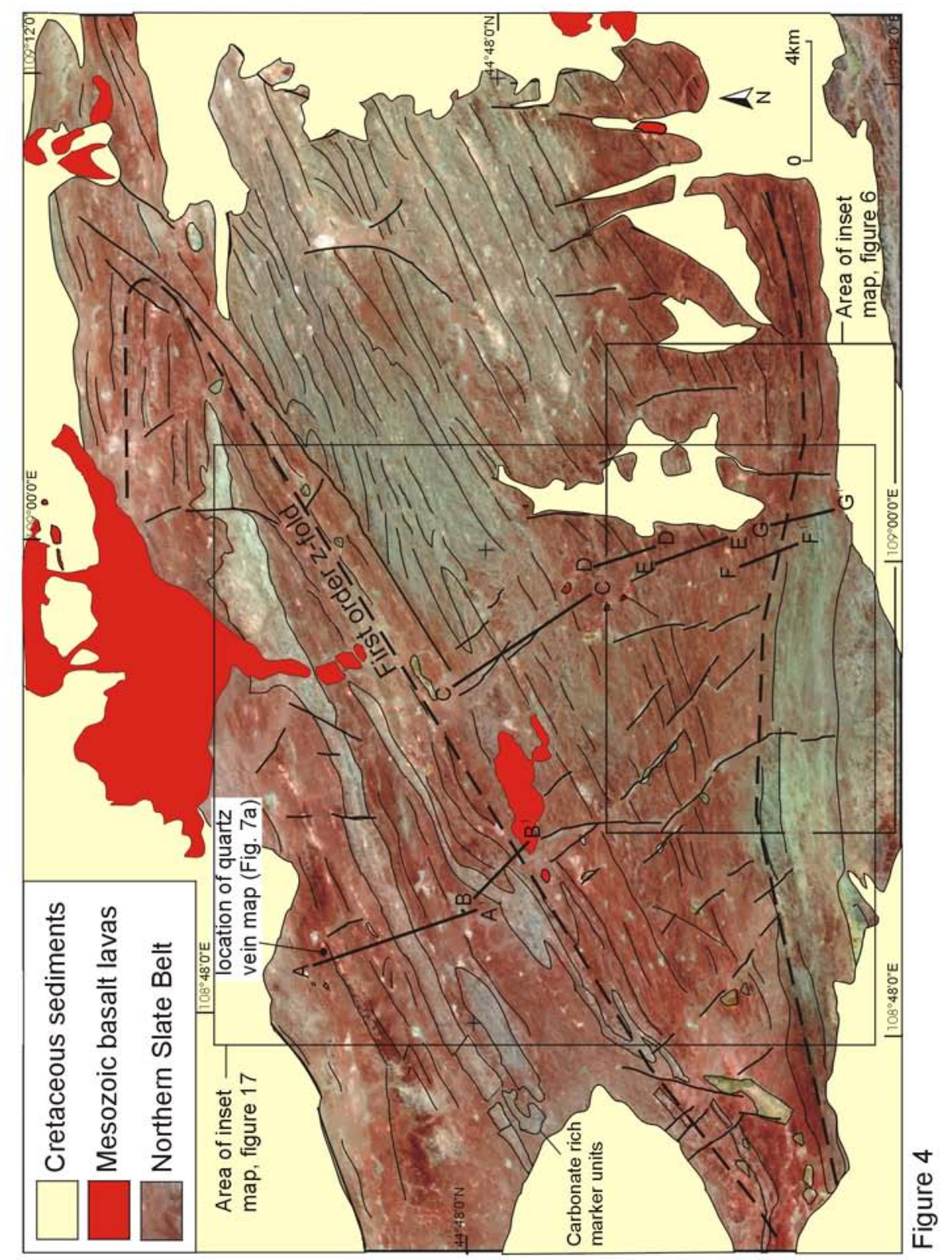



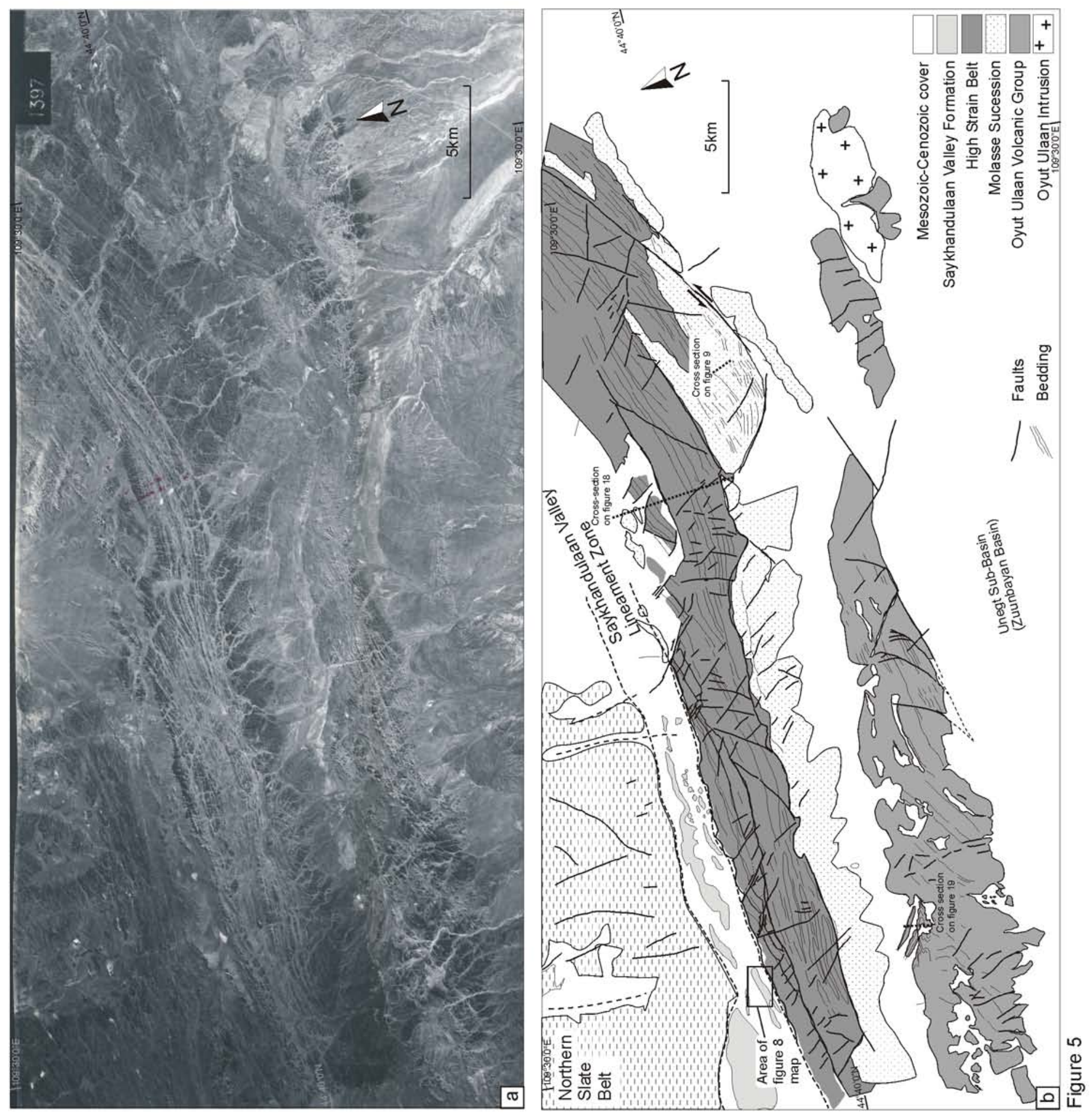

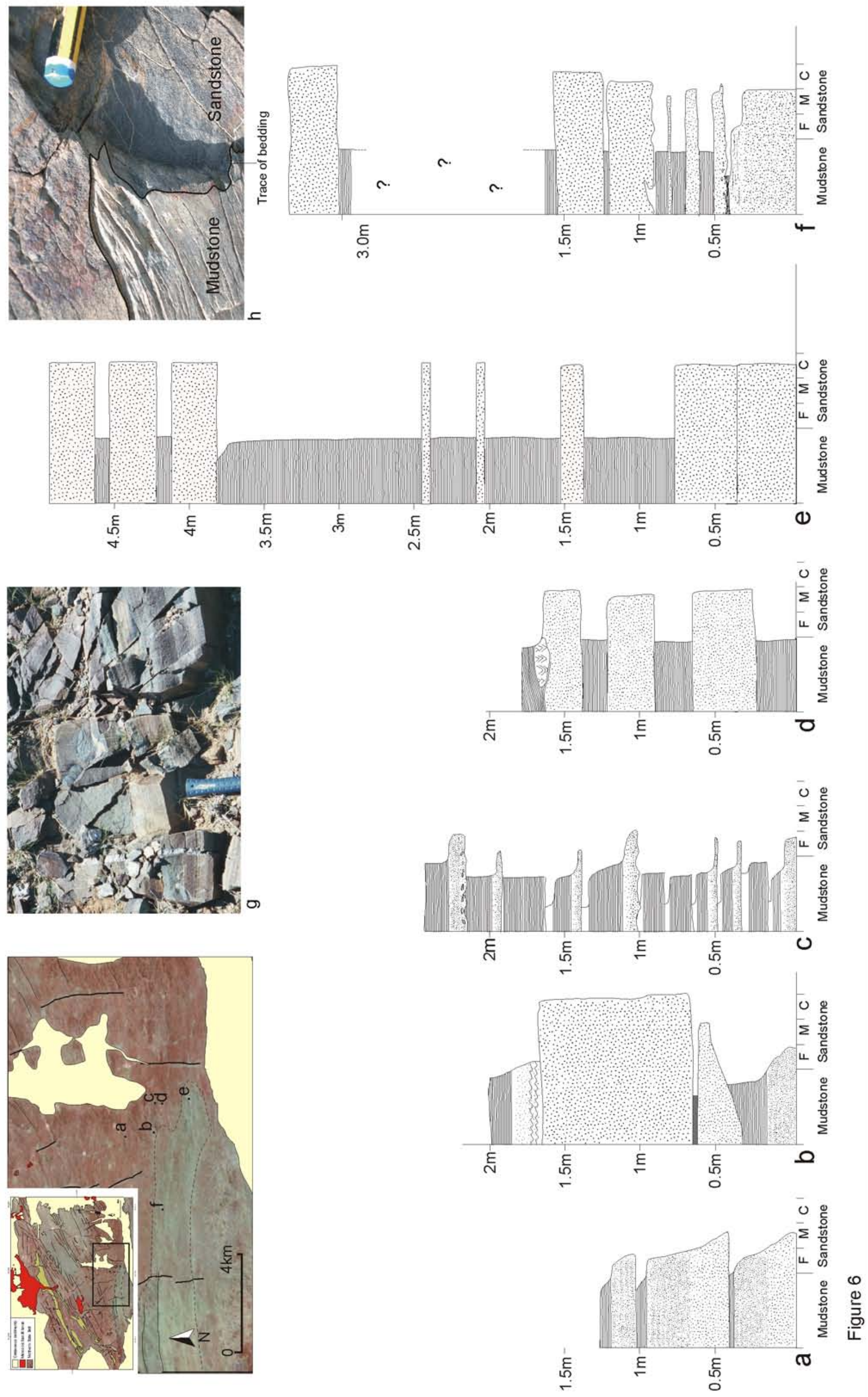

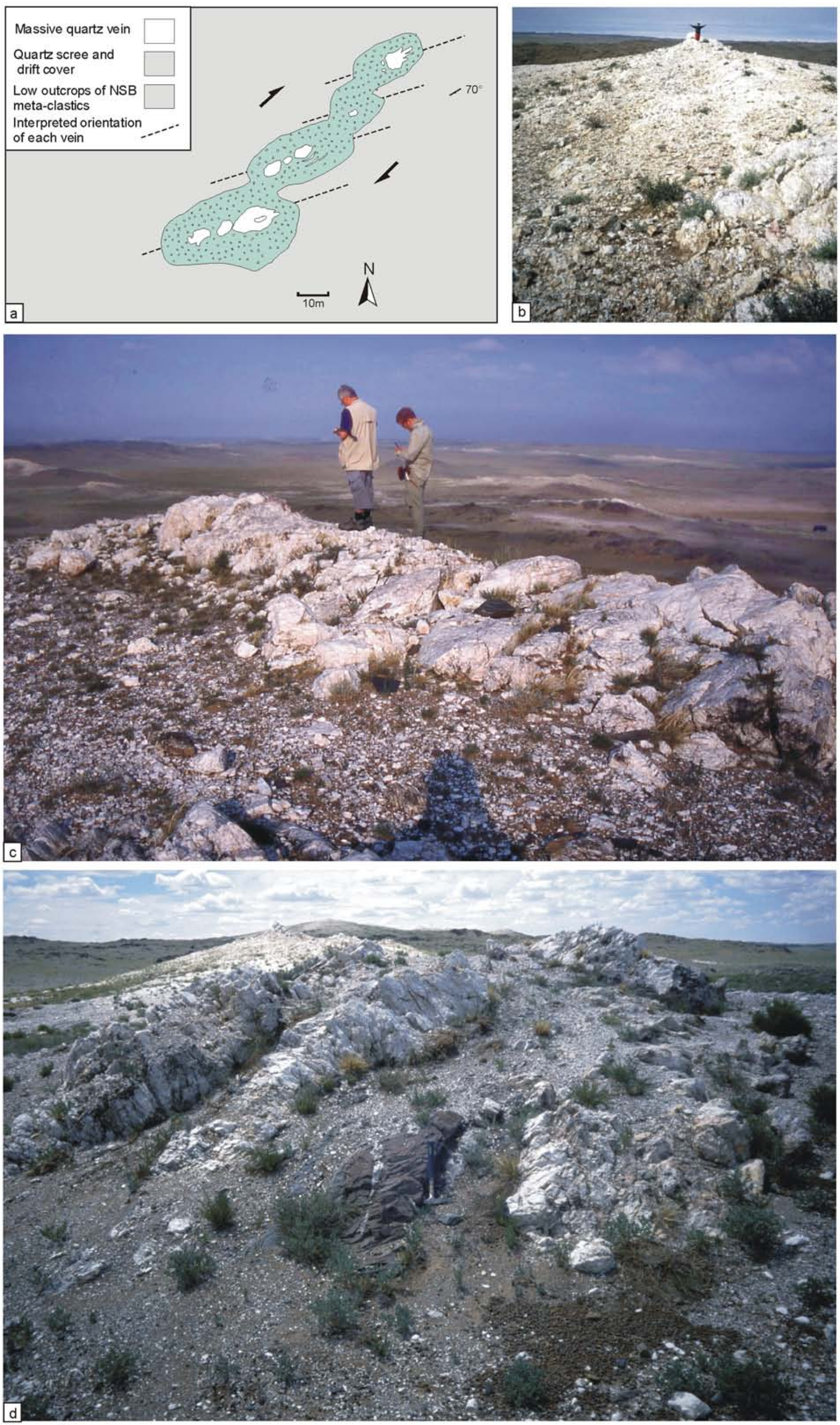

Figure 7 


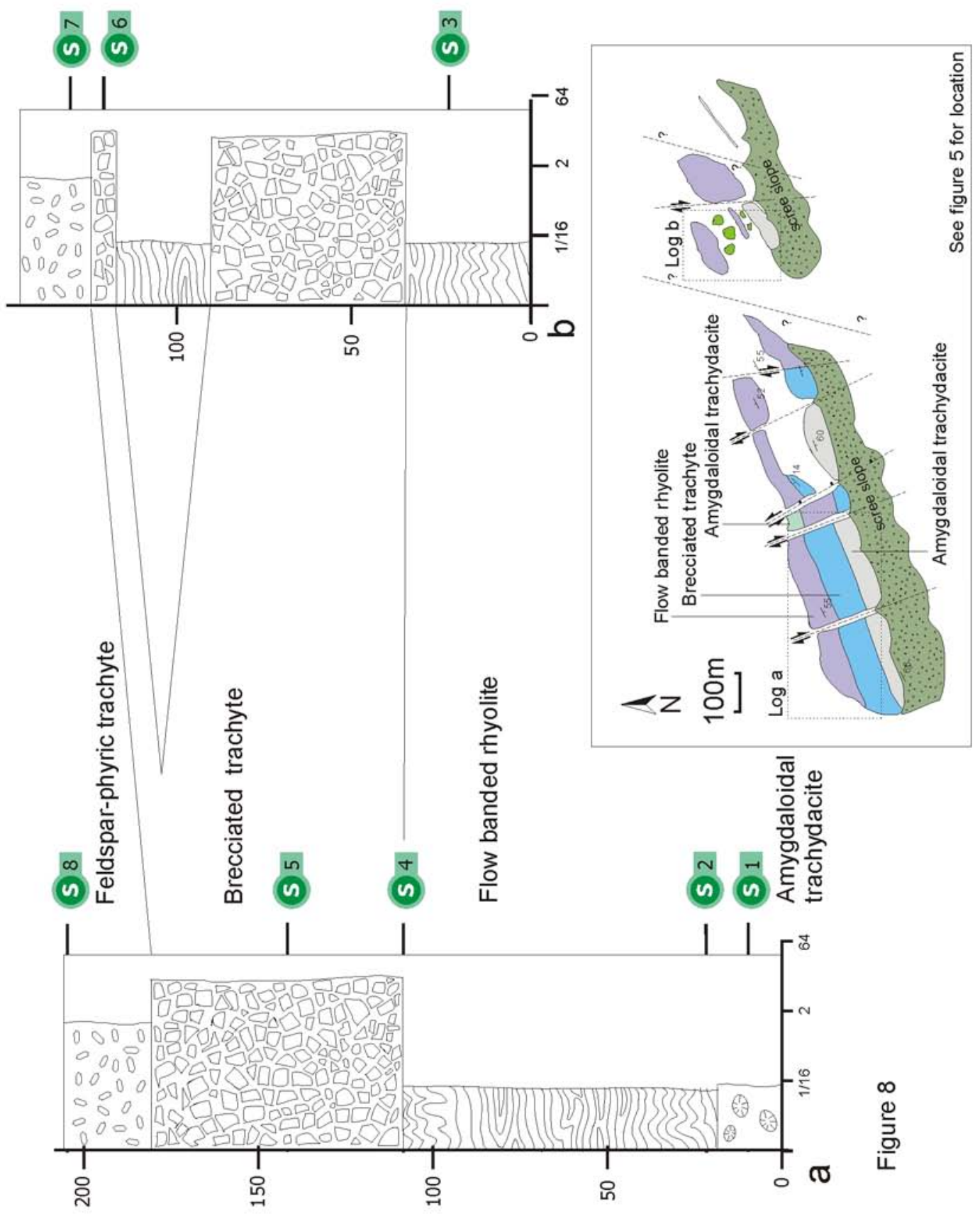



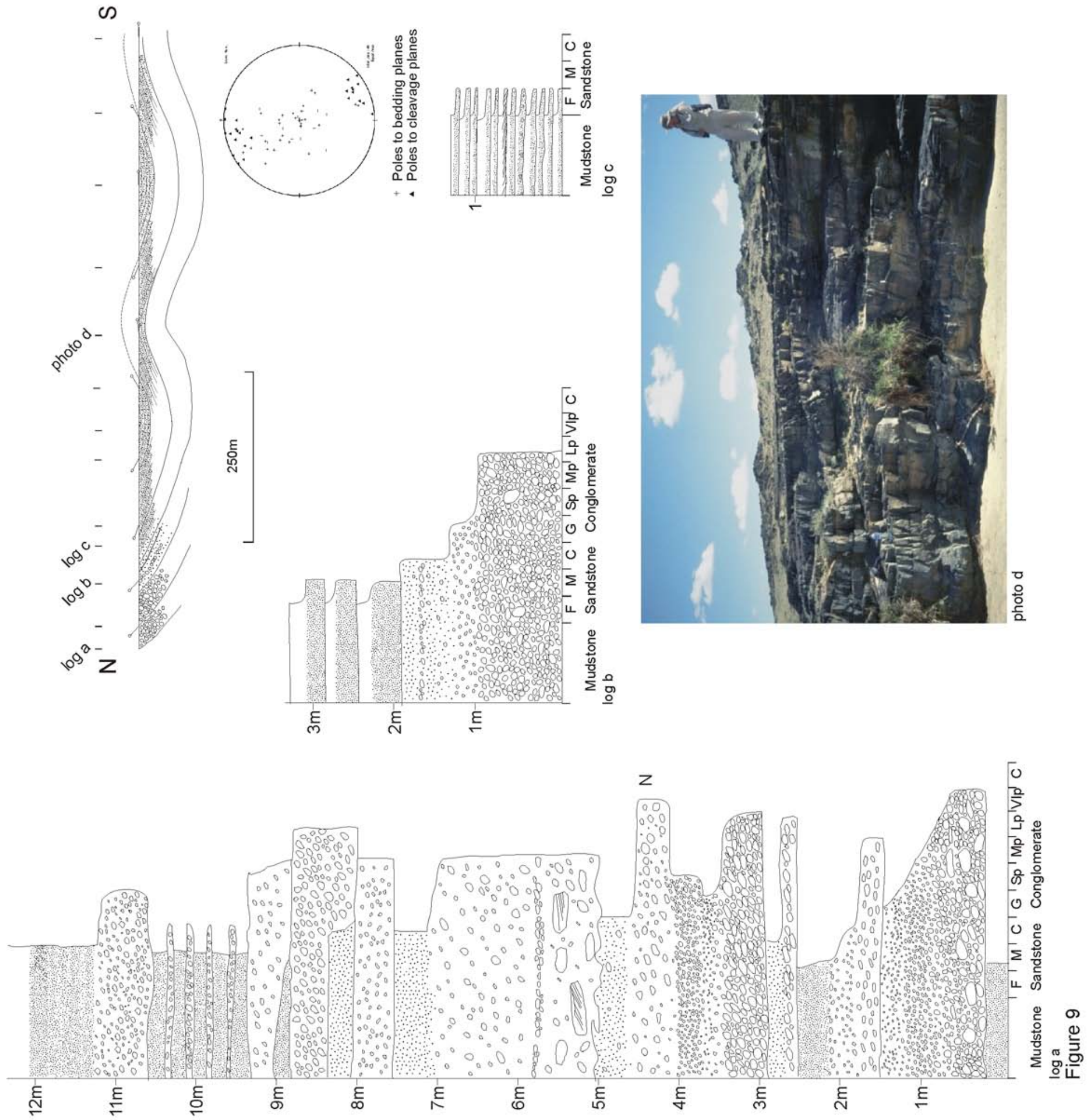


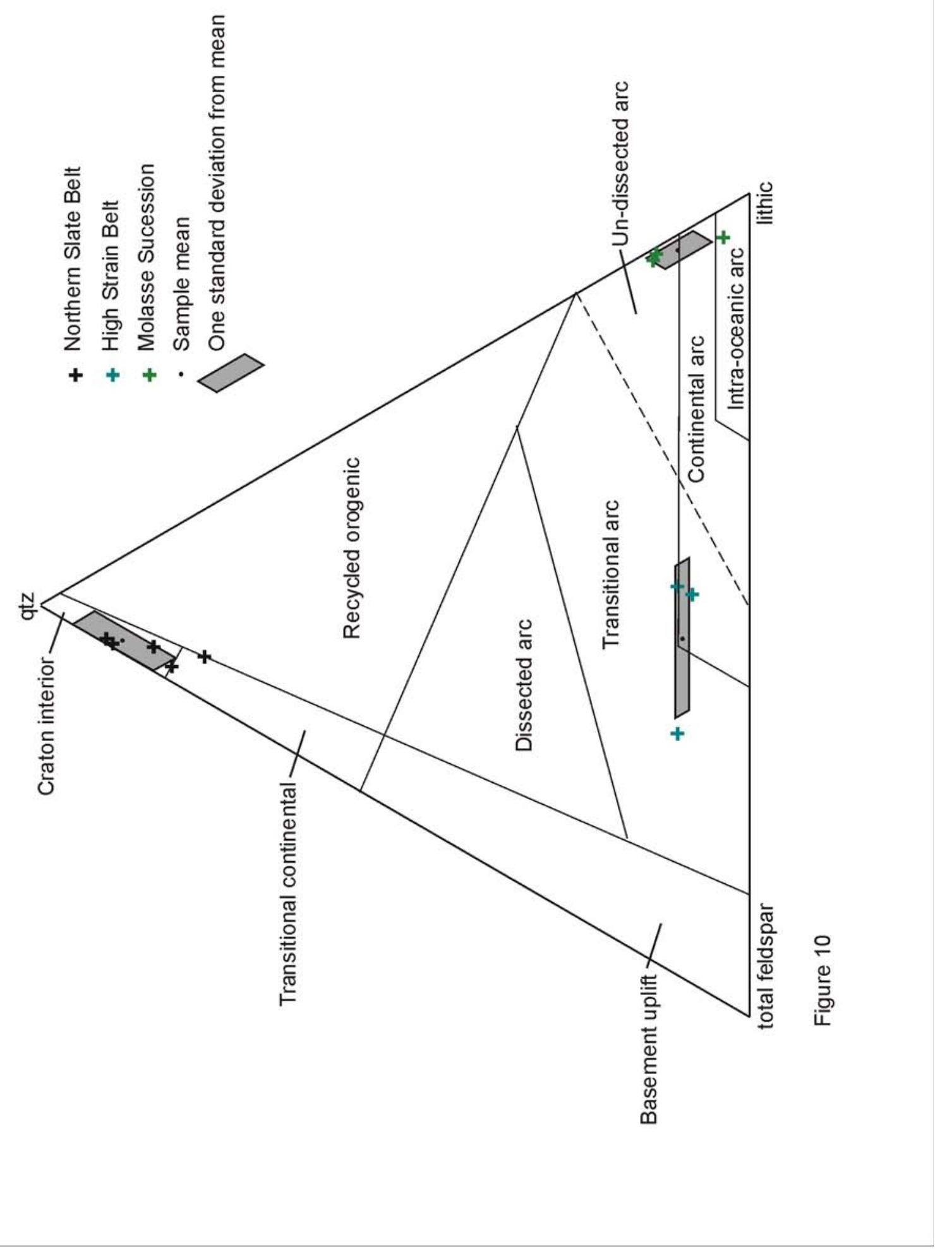




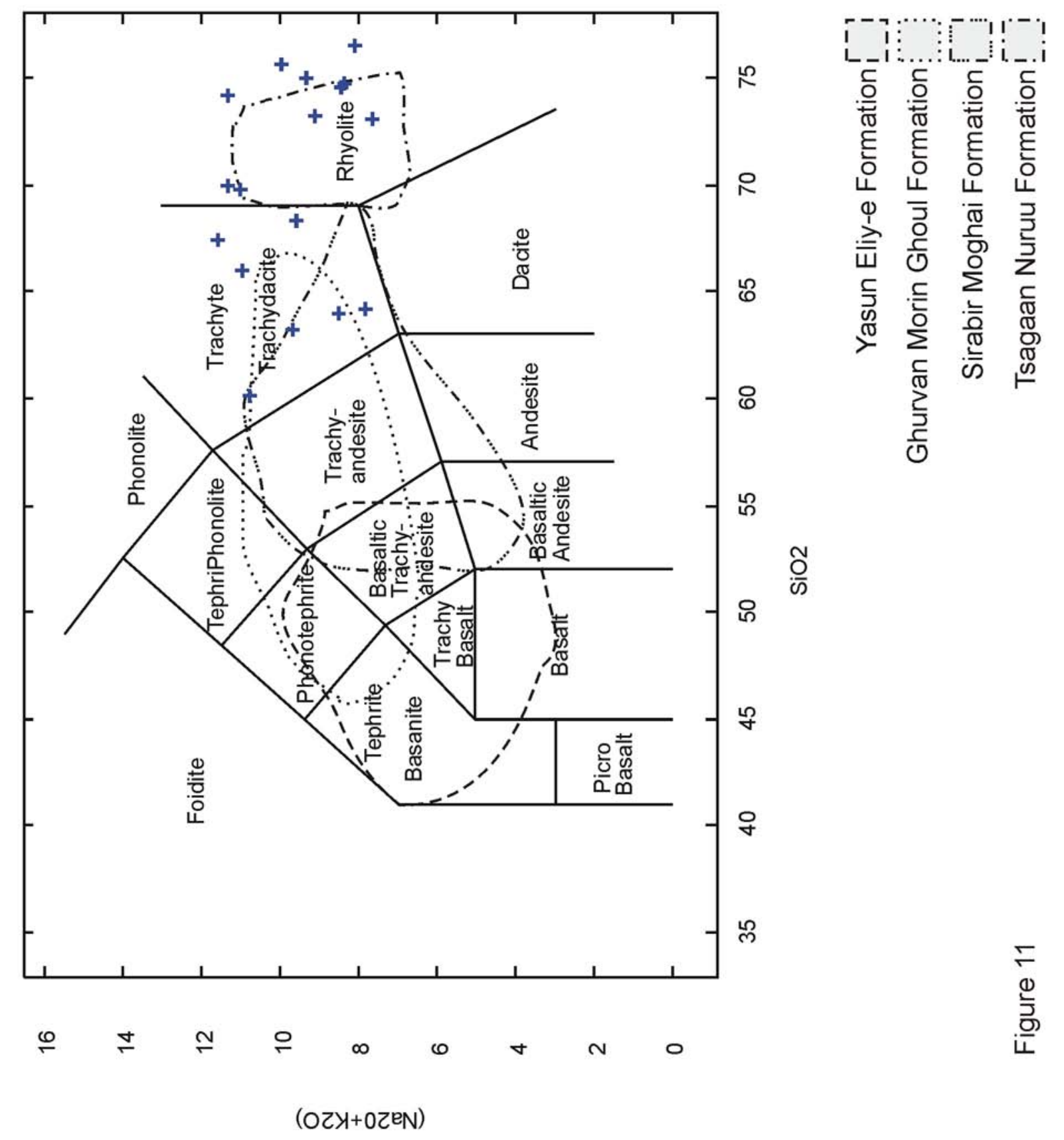




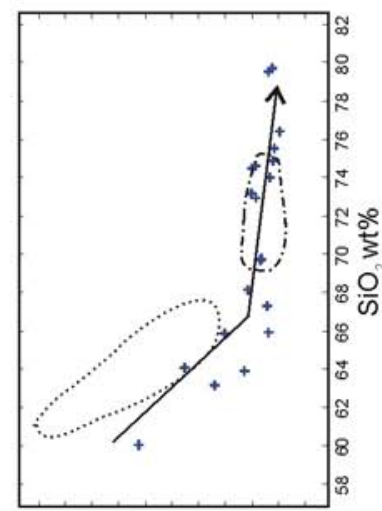

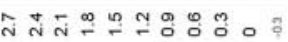

\%łM O6W

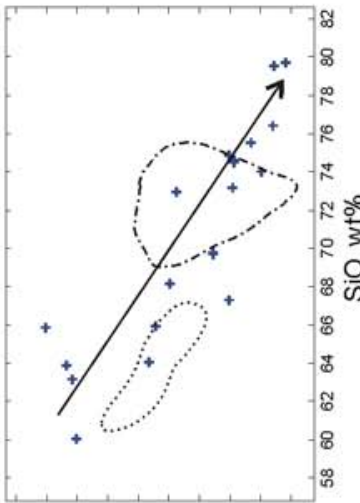

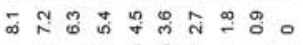
$\% 1 \mathrm{M}^{2} \mathrm{O}_{\mathrm{y}}$

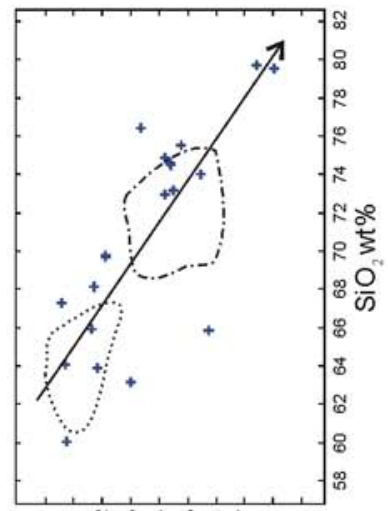

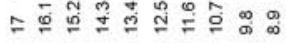
\%सM $\mathrm{O}^{\mathrm{I}} \mathrm{H}$

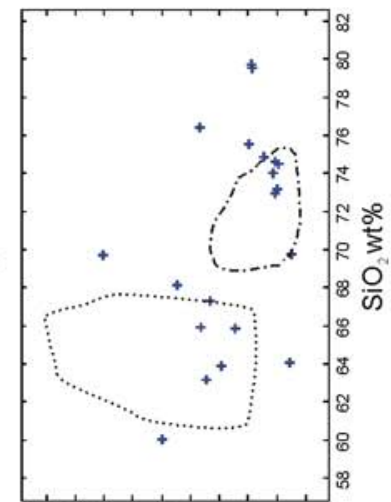

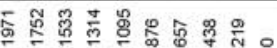
udd eg

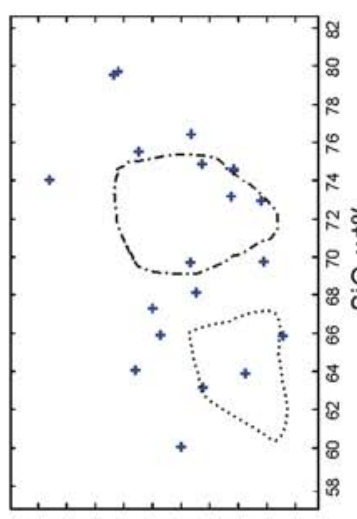

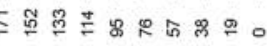
udd qy

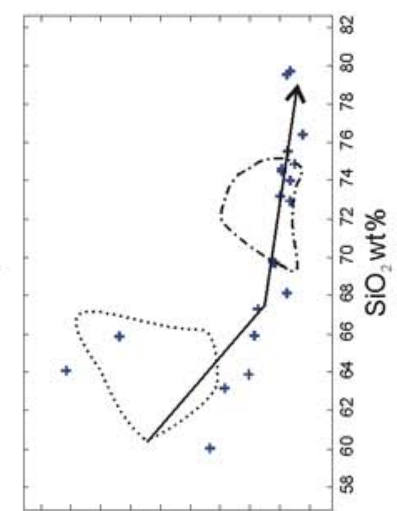

กำ กี $\%$ \% OEJ

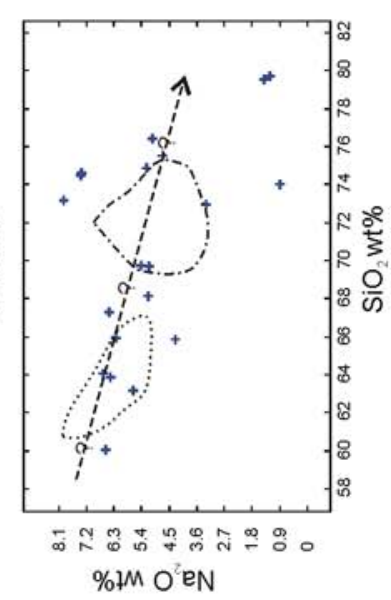

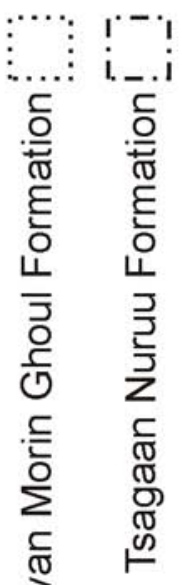

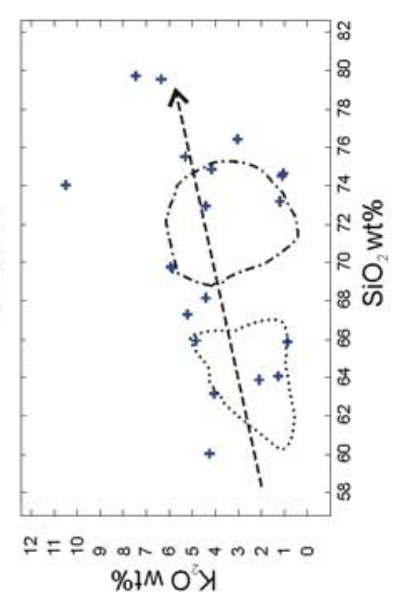

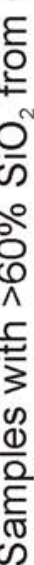

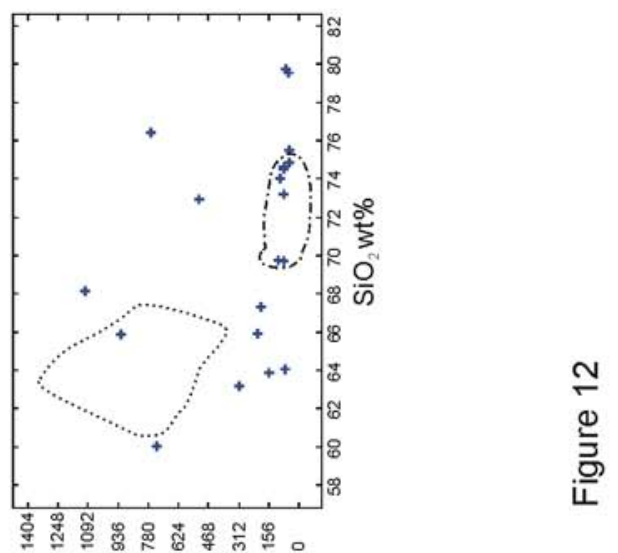




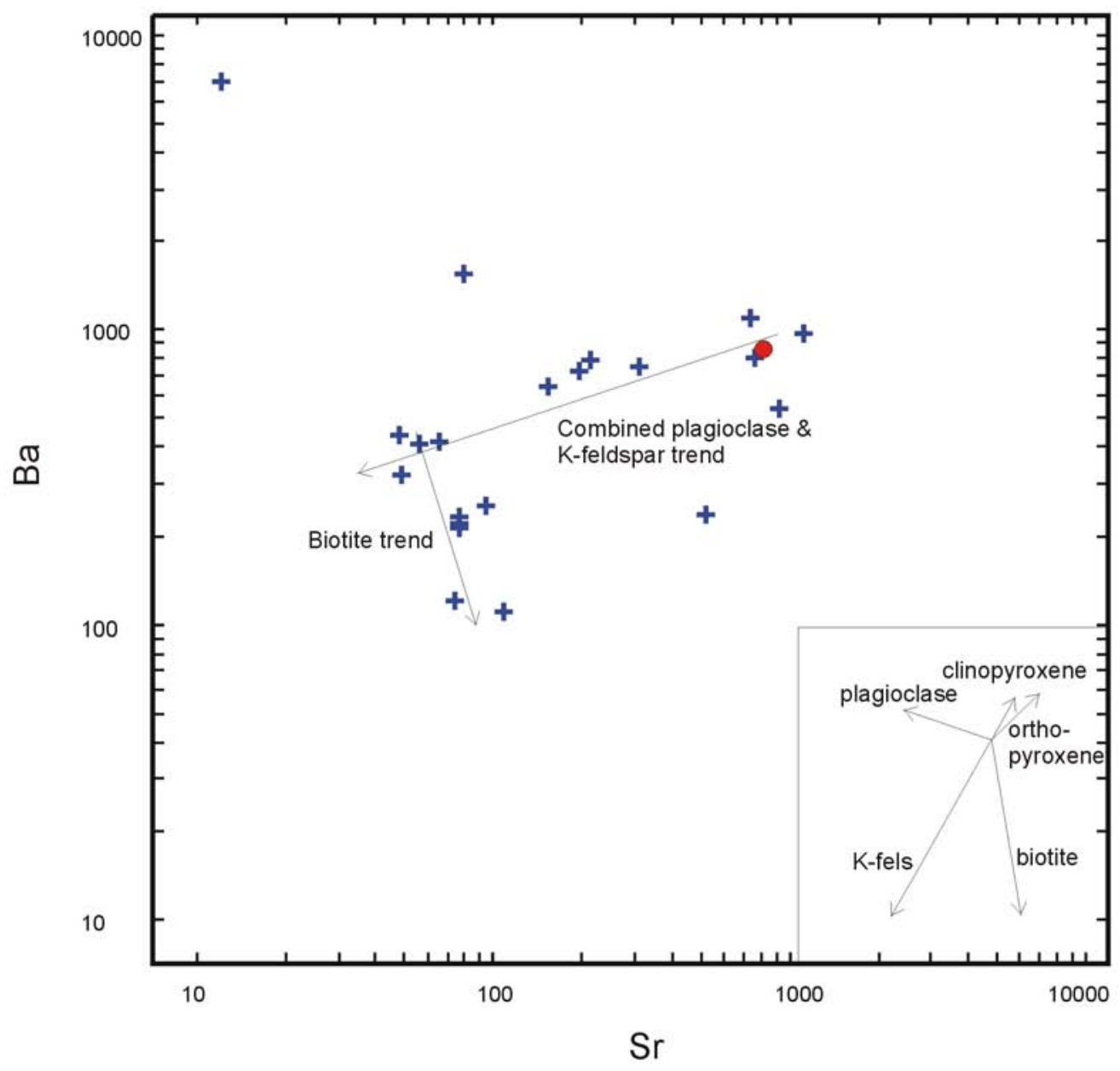

+ Saykhandulaan Valley Formation

Figure 13

- Average composition of Oyut Ulaan intrusion 

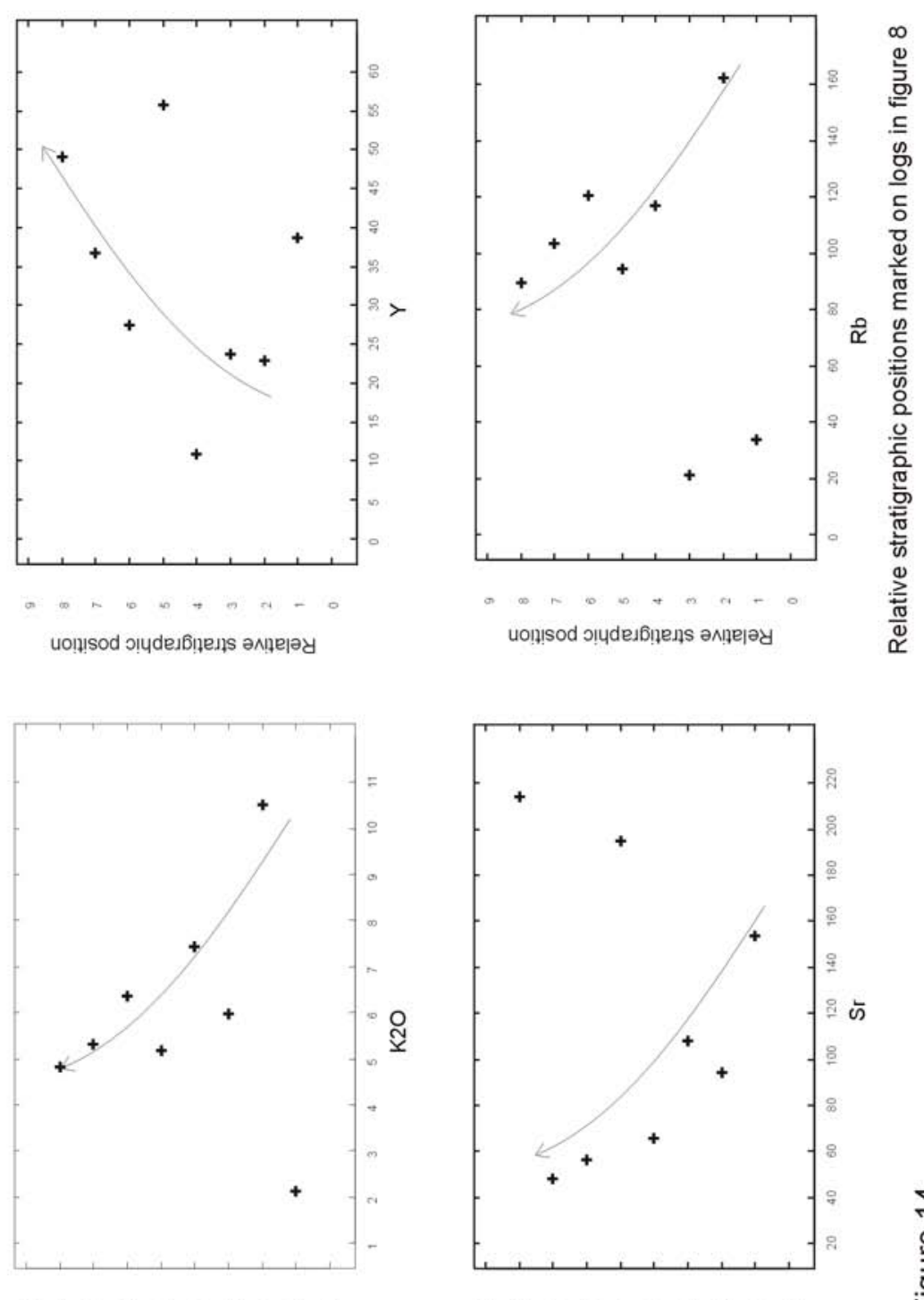

$\frac{⿱ 亠 䒑}{\frac{\square}{5}}$

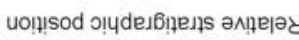

uo!̣ısod o!̣deı6!̣ens әмп̣е|әу 

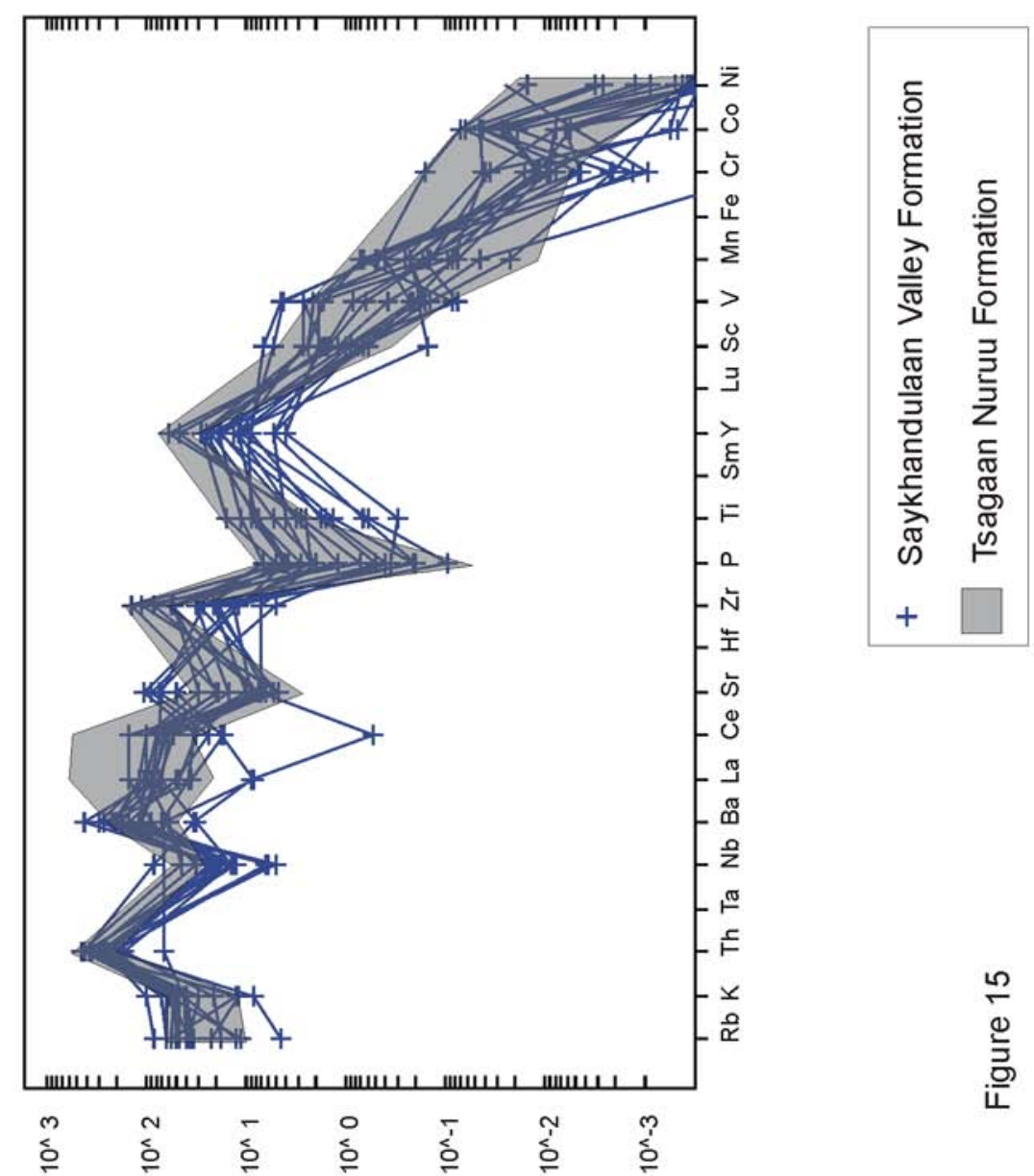

$\frac{2}{\frac{0}{2}}$ 


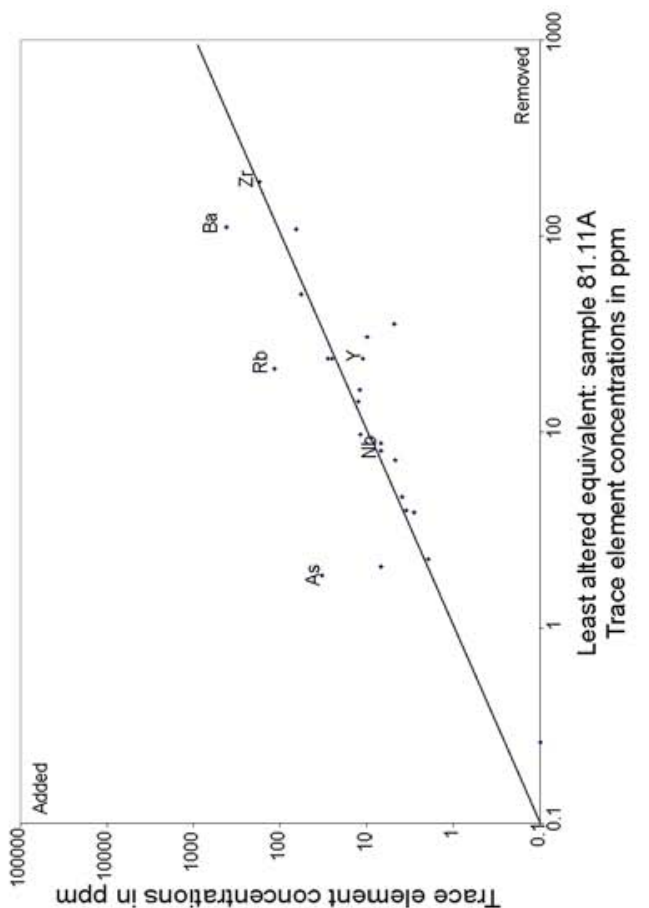

$\forall L^{\circ} 08$ ә әdures pəגə॥| $\forall$

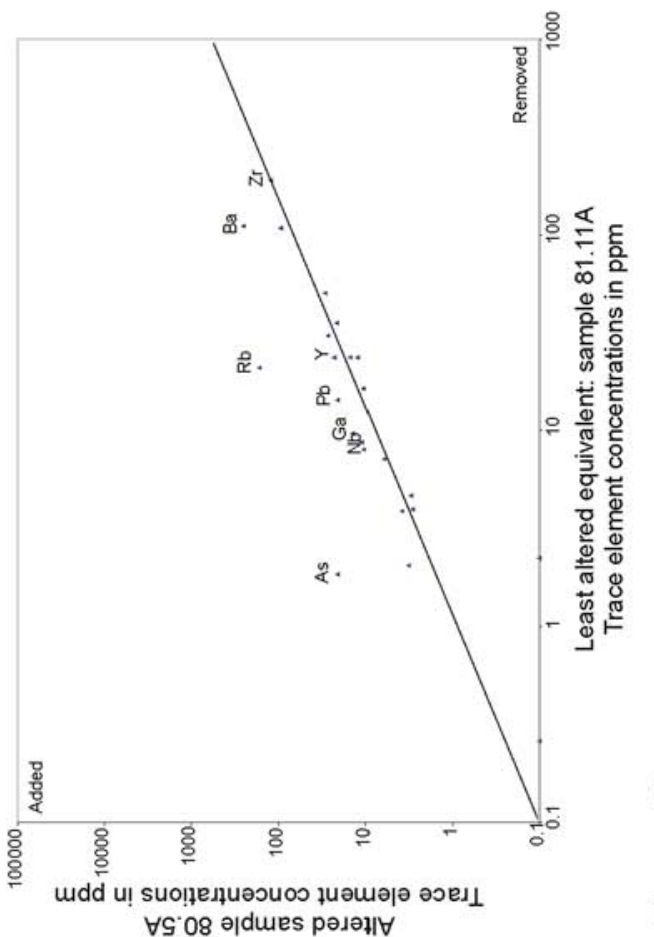

$\frac{\circ}{\frac{0}{0}}$ 


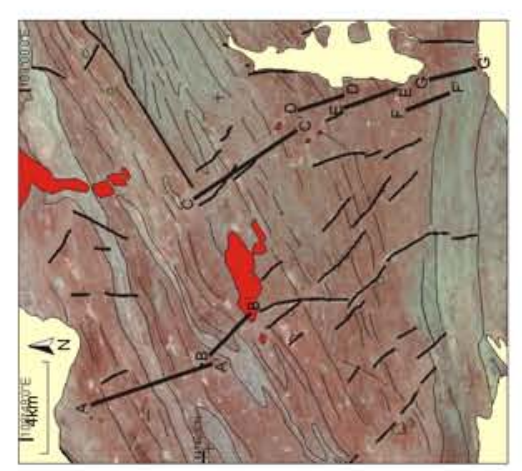

Ш
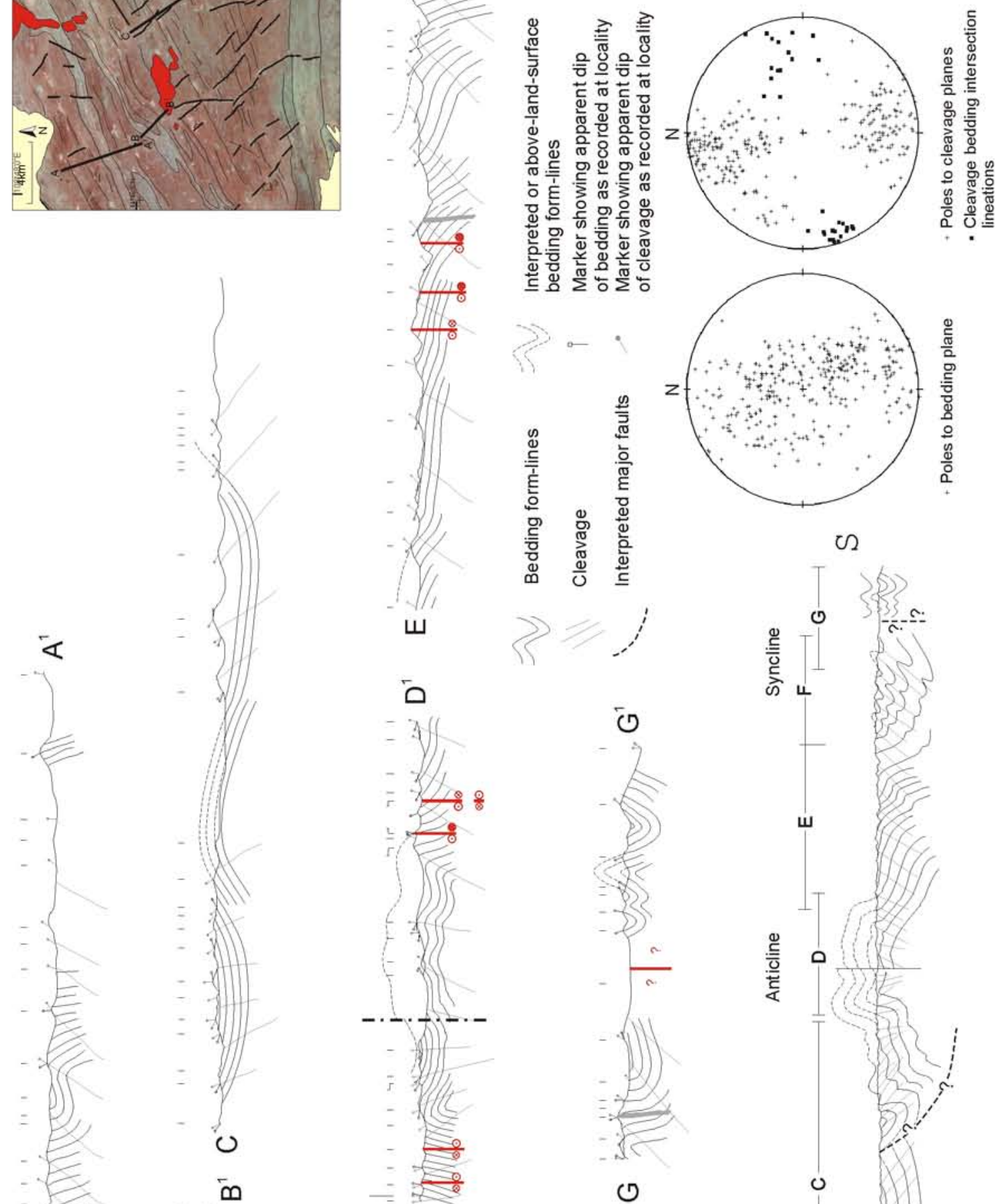

in
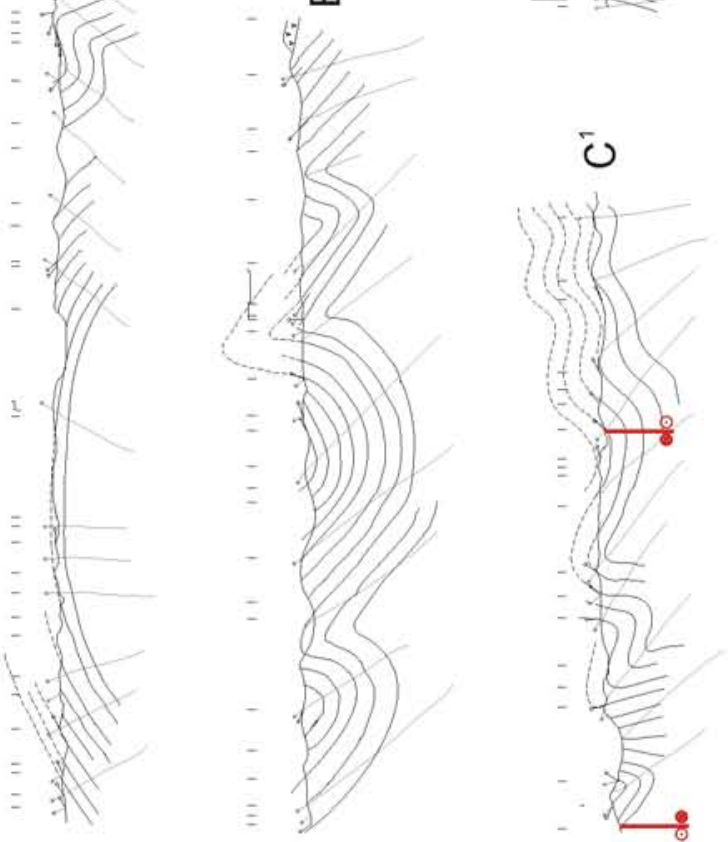

$\varangle$

$\infty$

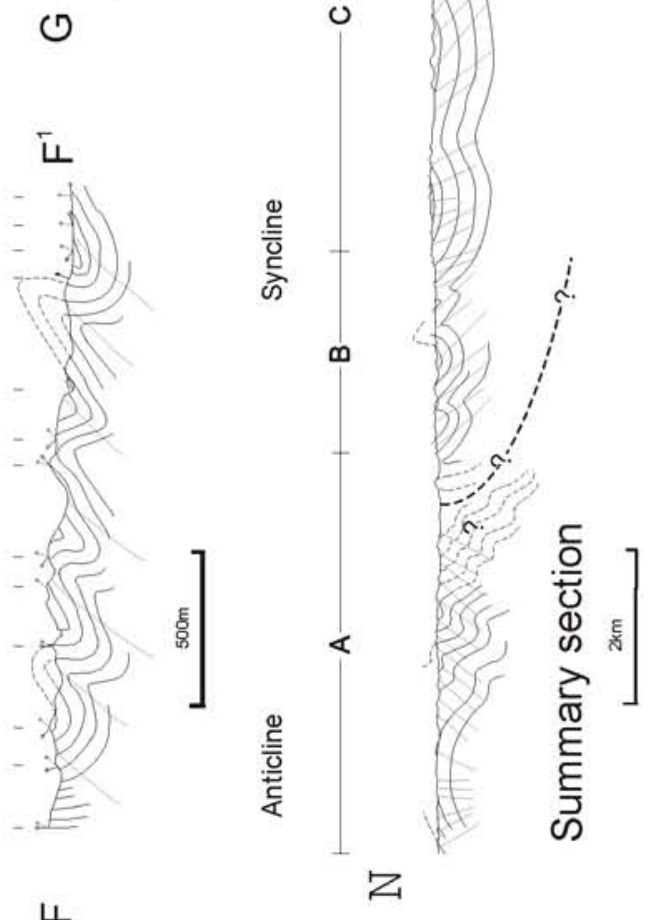

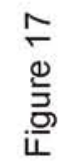

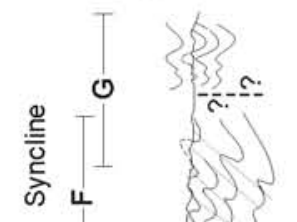



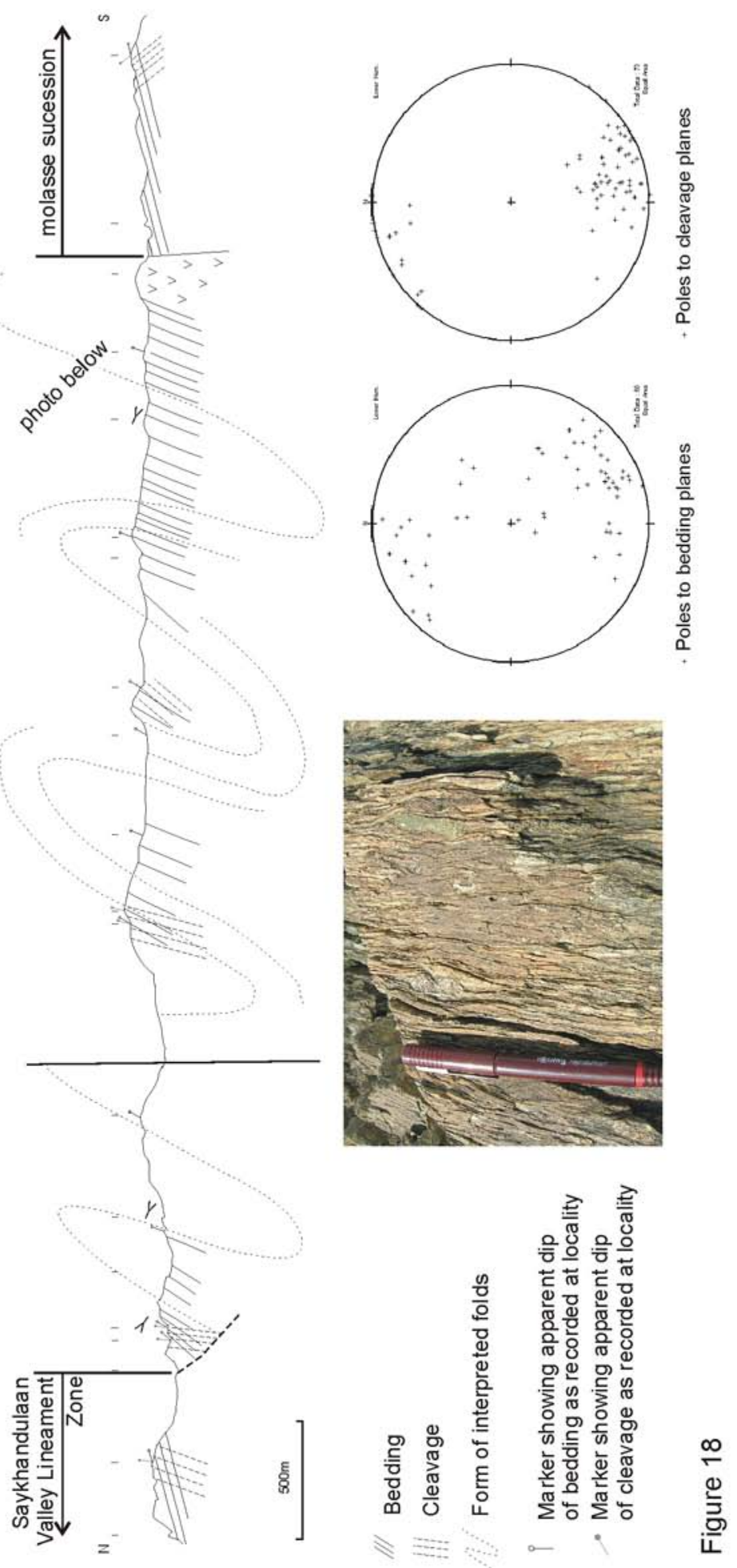


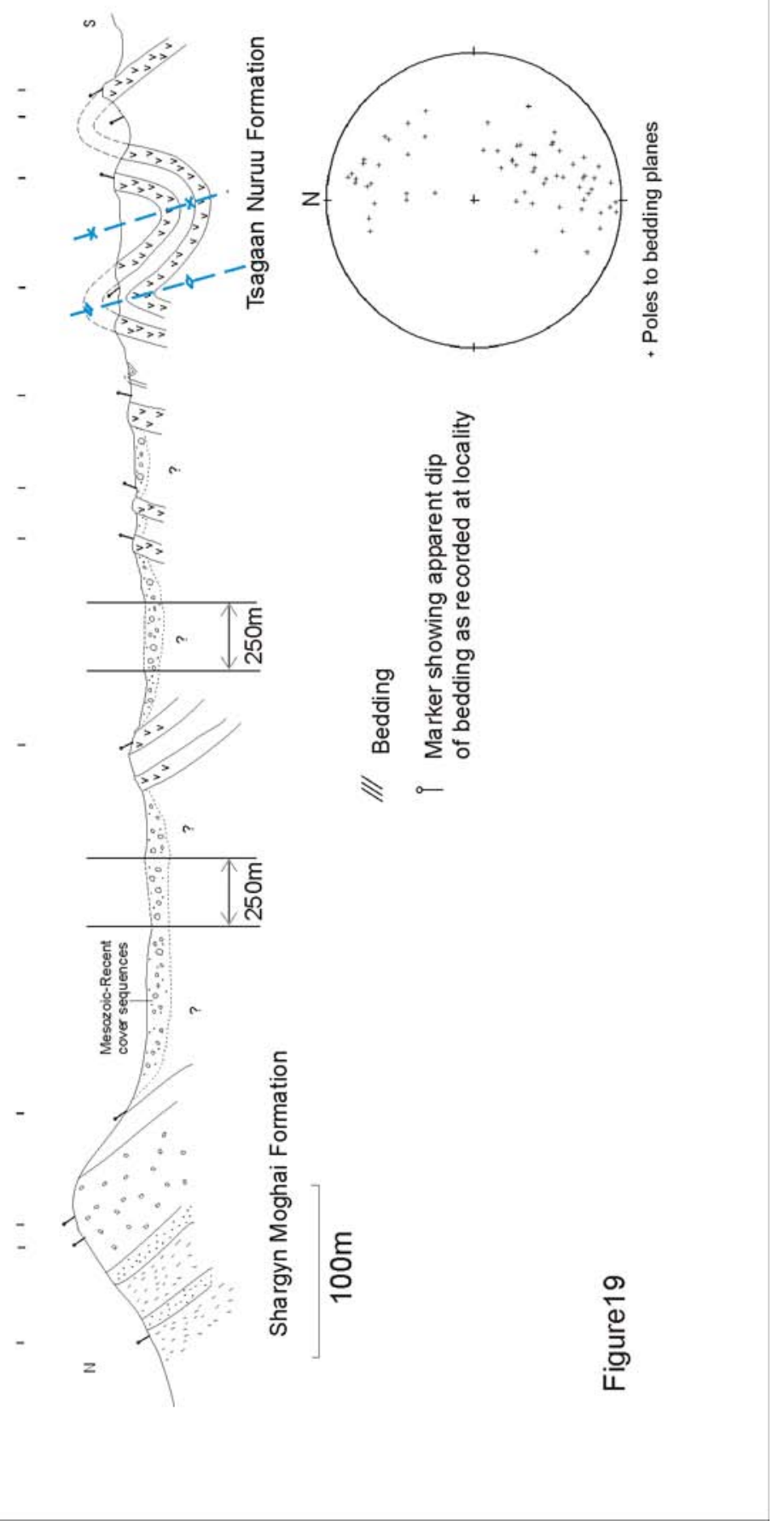



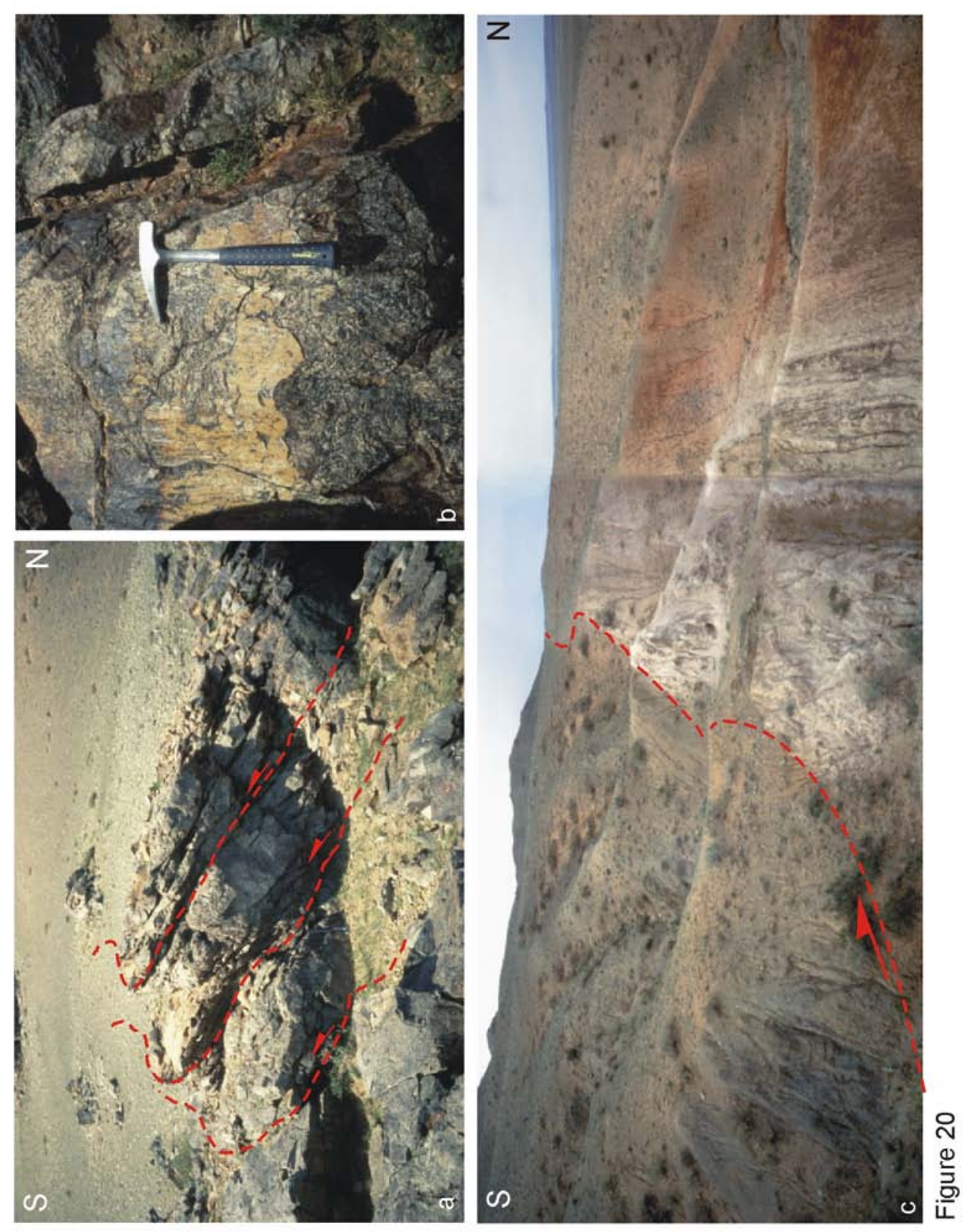


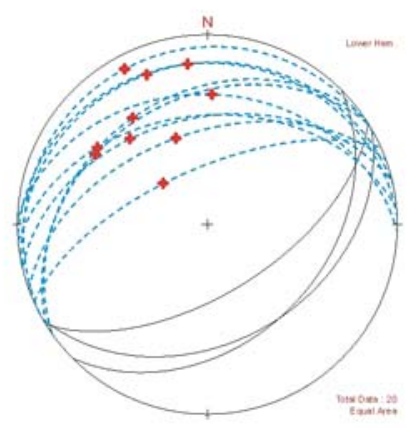

(a) Thrust orientations

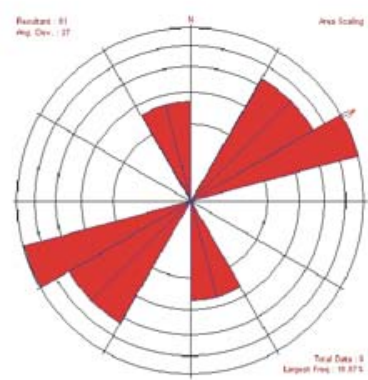

(c) Faults with apparent sinistral displacements

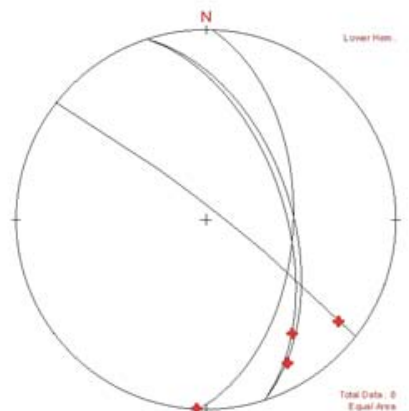

(b) Strike-slip \& oblique-slip faults from Saykhandulaan Valley

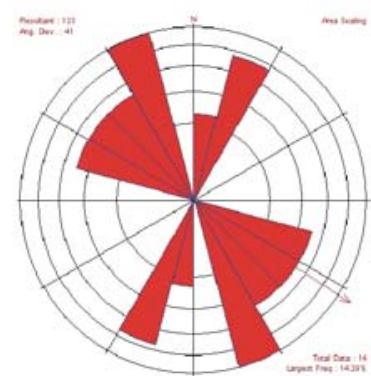

(d) Faults with apparent dextral displacements

Figure 21 


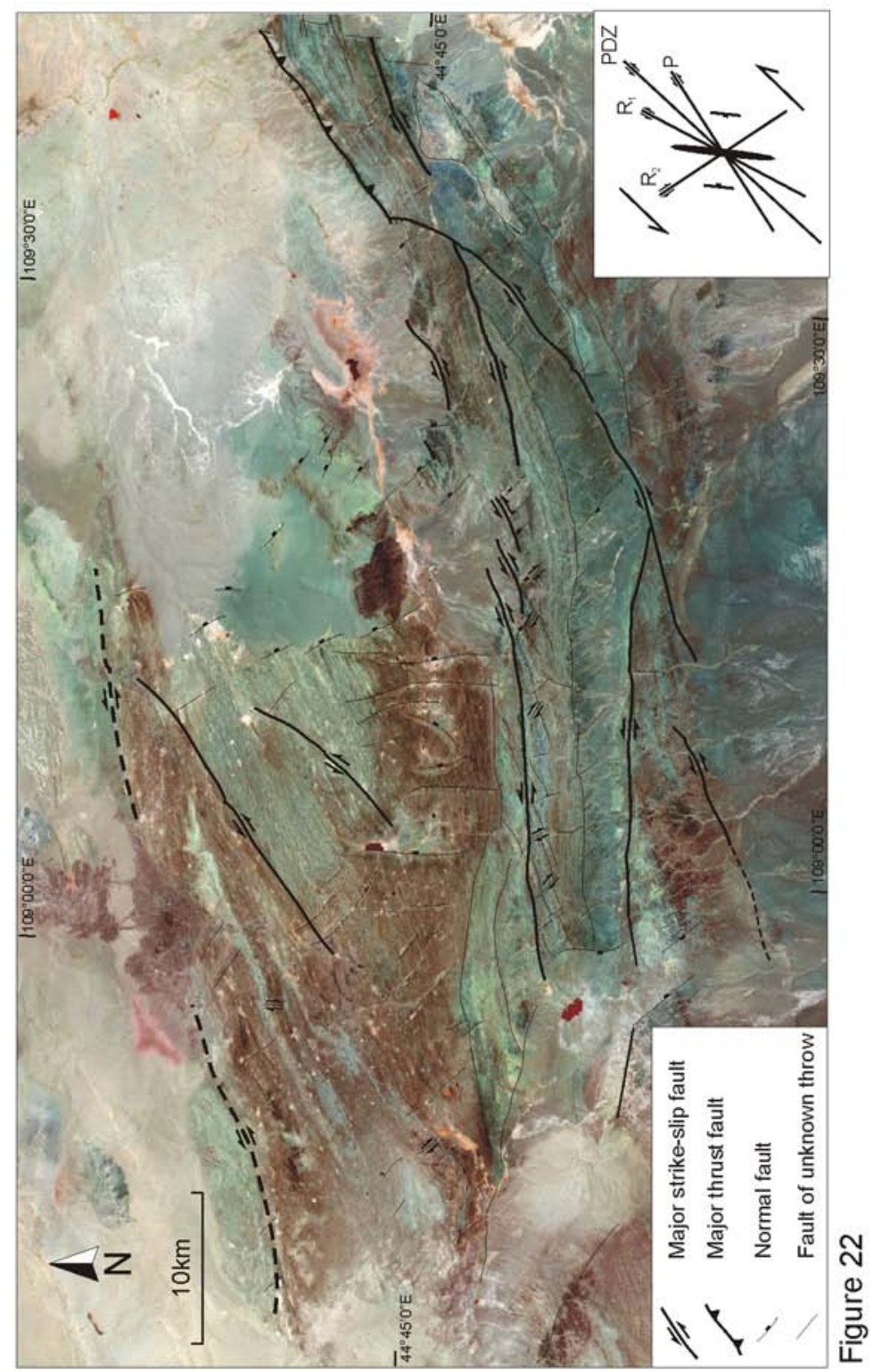




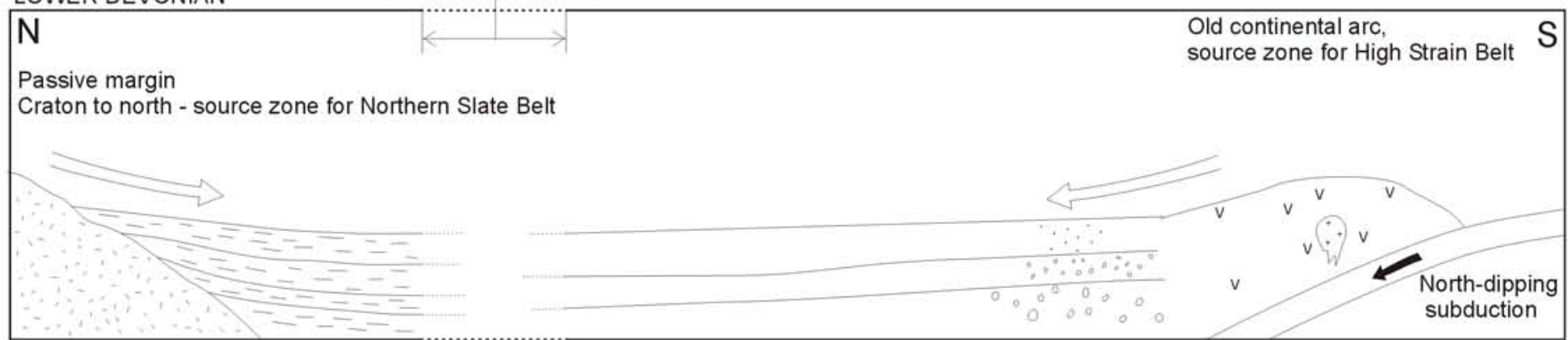

Back arc basin - the Gobi Altai Terrane

UPPER DEVONIAN

\section{$\mathrm{N}$}

Basin fills, compression

and inversion begins

Location of future
Saykhandulaan thrust

Saykhandulaan volcanism begins

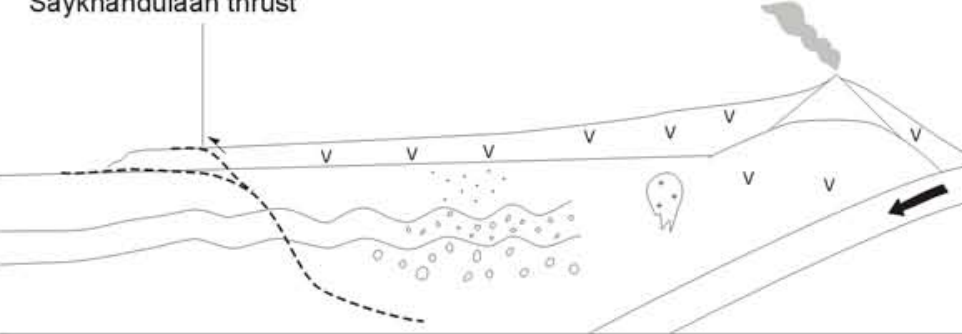

LOWER CARBONIFEROUS

$\begin{aligned} & \mathrm{N} \\ & \text { Basin inversion continues }\end{aligned}$
$\begin{gathered}\text { Thrusting brings High Strain Belt rocks up section } \\ \text { imbricates distal Saykhandulaan Valley Formation volcanics }\end{gathered}$

MID-UPPER CARBONIFEROUS

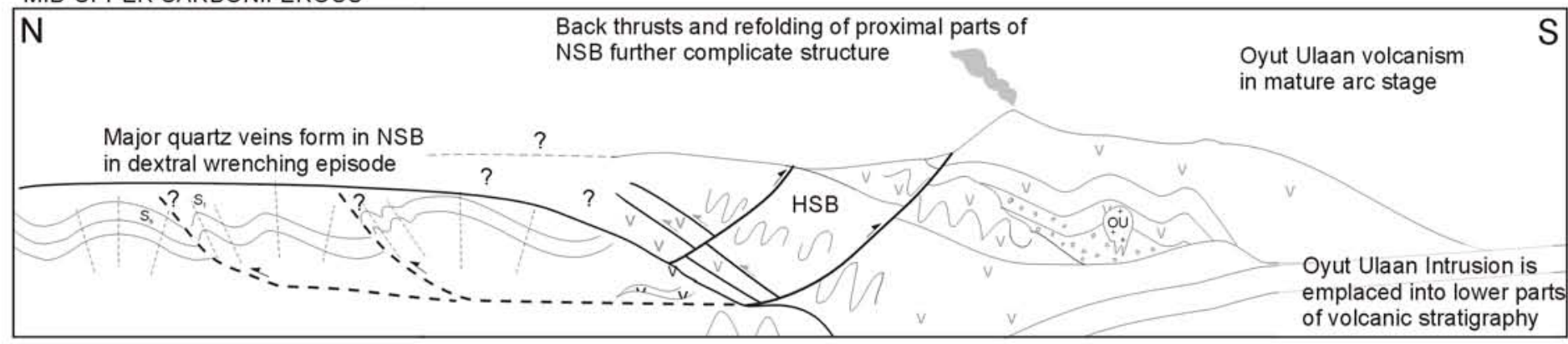

PERMIAN-RECENT

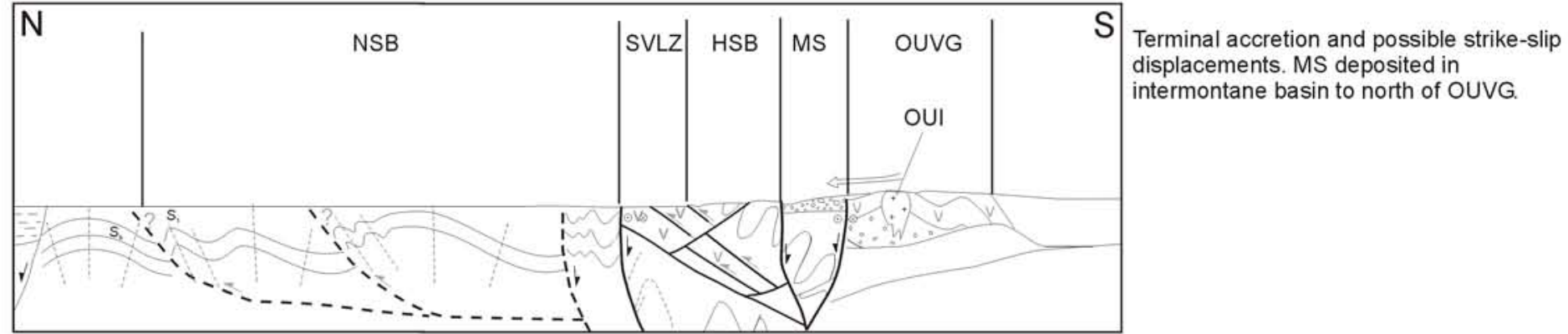

Figure 23 